This work is licensed under a Creative Commons Attribution License (CC BY 4.0).

\title{
The nautiloids from the Early Carboniferous Dalle à Merocanites of Timimoun, western Algeria
}

\author{
Dieter KORN ${ }^{1, *}$, Luyi MIAO² \& Jürgen BOCKWINKEL ${ }^{3}$ \\ ${ }^{1}$ Museum für Naturkunde, Leibniz Institut for Research on Evolution and Biodiversity, \\ Invalidenstraße 43, 10115 Berlin, Germany. \\ ${ }^{2}$ State Key Laboratory of Biogeology \& Environmental Geology, School of Earth Sciences, \\ China University of Geosciences, 388 Lumo Road, Wuhan, China. \\ ${ }^{3}$ Dechant-Fein-Straße 22, 51375 Leverkusen, Germany. \\ *Corresponding author: dieter.korn@mfn.berlin \\ 2Email: miaoluyi@cug.edu.cn \\ ${ }^{3}$ Email: jbockwinkel@t-online.de \\ ${ }^{1}$ urn:lsid:zoobank.org:author:286CA4F3-7EBC-4AEF-A66A-B2508D001367 \\ ${ }^{2}$ urn:1sid:zoobank.org:author:2171F5FC-45B5-452B-A134-CD1308B3A085 \\ ${ }^{3}$ urn:1sid:zoobank.org:author:F7FE7EEA-B678-4FEE-879C-8C429F66BF3A
}

\begin{abstract}
Early Carboniferous coiled nautiloids from North Africa are virtually unknown. An assemblage of nine species, all from the family Trigonoceratidae, from the Dalle à Merocanites (Tournaisian-Viséan boundary interval) of Timimoun in western Algeria is described, being the most diverse Carboniferous nautiloid assemblage known from North Africa but much less diverse than the time-equivalent assemblages from Belgium and Ireland. The assemblage consists of the species Maccoyoceras pentagonum sp. nov., Lispoceras orbis sp. nov., Thrincoceras devolvere sp. nov., Rineceras multituberculatum sp. nov., Rineceras rectangulatum sp. nov., Vestinautilus padus sp. nov., Vestinautilus concinnus sp. nov., Planetoceras destrictum sp. nov. and Planetoceras transforme sp. nov. A morphometric analysis of Maccoyoceras pentagonum sp. nov. and Lispoceras orbis sp. nov. shows that the intraspecific variation in these species is within rather narrow limits.
\end{abstract}

Keywords. Nautiloidea, Early Carboniferous, Algeria, morphology, taxonomy.

Korn D., Miao L. \& Bockwinkel J. 2022. The nautiloids from the Early Carboniferous Dalle à Merocanites of Timimoun, western Algeria. European Journal of Taxonomy 789: 104-129.

https://doi.org/10.5852/ejt.2022.789.1635

\section{Introduction}

The evolutionary history of Carboniferous nautiloids is far less well-studied than that of ammonoids. This is partly due to the mostly much rarer finds; the fossil record of nautiloids is incomplete because of many stratigraphic gaps. For example, little is known about coiled nautiloids at the DevonianCarboniferous transition, as no earliest Tournaisian representatives are yet known (Dzik 1984; Dzik \& 
Korn 1992). Only from the middle to late Tournaisian, the assemblages are quite species-rich with a broad morphological spectrum known from several regions.

Coiled nautiloids are often recovered as 'accompanying fauna' when collecting ammonoids, but they are usually far behind the ammonoids in terms of specimen numbers. This is possibly owing to the facies; Palaeozoic ammonoids are particularly common in sedimentary rocks of the deep shelf, while nautiloids tended to prefer shallower areas. Therefore, coiled nautiloids outnumber ammonoids only in certain lithologies and regions, such as in the Carboniferous limestones of Belgium (de Koninck 1844, 1878, 1880; Demanet 1938) and Ireland (Sowerby 1825; Foord 1900, 1901; Histon 1999), which globally yield the most diverse Early Carboniferous nautiloid assemblages. In contrast to the assemblages of Ireland and Belgium, Early Carboniferous coiled nautiloids have only occasionally been collected in greater diversity in other regions. These regions include the American Midwest (e.g., Hyatt 1893; Miller et al. 1933; Miller \& Garner 1953; Niko \& Mapes 2015, 2016) as well as the Ural Mountains (Shimansky 1967) and the Rhenish Mountains (Holzapfel 1889; Schmidt 1951).

Apparently, the considerably poorer fossil record of the Carboniferous nautiloids also had a major impact on the research history of these organisms. In contrast to the ammonoids, which were intensively collected and studied for stratigraphic purposes for much of the $20^{\text {th }}$ century, there was no such need for the coiled nautiloids. It is therefore probably no coincidence that the first revision of nautiloids from Foord's monographs did not take place until a hundred years later (Histon 1999). The nautiloids in the monographs of de Koninck have not yet been revised at all.

Early Carboniferous coiled nautiloids from North Africa are almost unknown; there is only one short study (Delépine 1939) describing two specimens from Erfoud (Morocco). Here, we describe an assemblage of nine species from the Dalle à Merocanites (Tournaisian-Viséan boundary interval) of Timimoun in western Algeria. In contrast to the occurrences in Ireland and Belgium, which are closely associated with Waulsortian mudmounds, the new collections come from deposits of the deeper shelf. We compare it in terms of morphological diversity with time-equivalent records from other regions, with a special focus on Ireland and Belgium.

\section{Material and methods}

We examined a material consisting of a total of 56 specimens. All specimens are from the Dalle à Merocanites (Conrad 1984) of outcrops in the Sebkha de Timimoun (Fig. 1), $14.5 \mathrm{~km}$ west-southwest of Timimoun (Gourara, Algeria). The nautiloids occur there together with the species-rich AmmonellipsitesMerocanites ammonoid assemblage, which is present in considerably larger numbers of individuals (637 specimens of ammonoids belonging to 16 species were described by Ebbighausen et al. 2010).

The Dalle à Merocanites is a limestone unit about $1.90 \mathrm{~m}$ thick; it consists of a few, mainly sideritic and dolomitised nodular layers separated by strongly weathered shales. Like the ammonoids, the nautiloids from this unit are rather well preserved, although some details have been destroyed by dolomitisation. Several specimens are preserved including the protoconch and the body chamber and show an excellently preserved shell surface with the most delicate details.

The material studied here is kept in the fossil cephalopod collection at the Museum für Naturkunde, Berlin under the catalogue numbers MB.C.30378 to MB.C.30386. The specimens have conch diameters of up to $90 \mathrm{~mm}$; this means that they do not reach the size of some of the Irish and Belgian time equivalent individuals. This is partly due to the composition of the Timimoun assemblage, which exclusively consists of the superfamily Trigonoceratoidea Hyatt, 1884, whereas the assemblages from Ireland and Belgium contain large-sized representatives of the Liroceratoidea Miller \& Youngquist, 1949 and Aipoceratoidea Hyatt, 1883. 

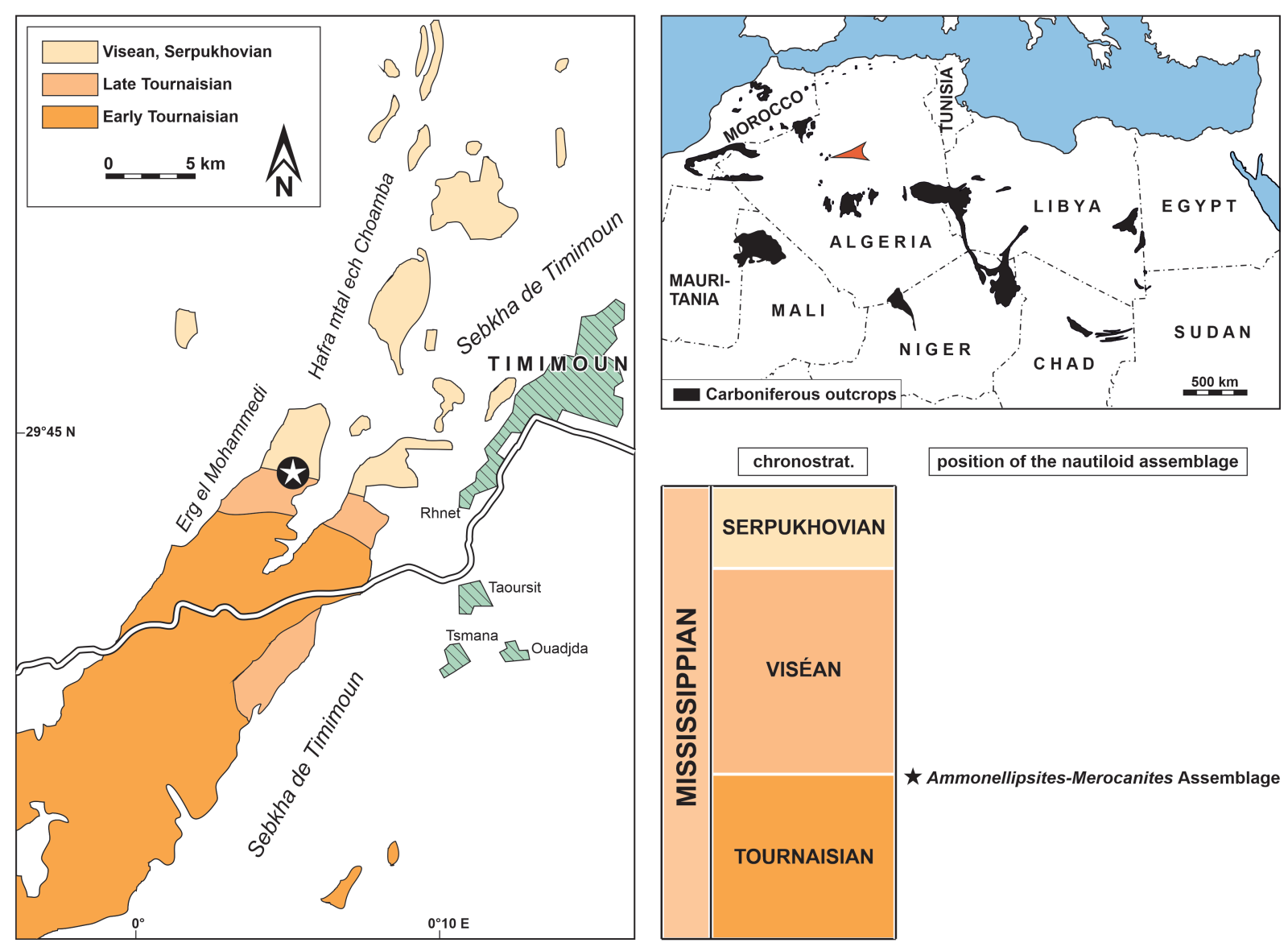

Fig. 1. Geographic and stratigraphic position of the fossil site in the Dalle à Merocanites near Timimoun with the nautiloid assemblage described here.

The following species are represented in the Timimoun assemblage:
Maccoyoceras pentagonum sp. nov.
34 specimens
Lispoceras orbis sp. nov.
15 specimens
Thrincoceras devolvere sp. nov.
1 specimen
Rineceras multituberculatum sp. nov.
1 specimen
Rineceras rectangulatum $\mathrm{sp}$. nov.
1 specimen
Vestinautilus padus sp. nov.
1 specimen
Vestinautilus concinnus sp. nov.
1 specimen
Planetoceras destrictum sp. nov.
1 specimen
Planetoceras transforme sp. nov.
1 specimen

The morphological description of the material follows, to the extent possible, the scheme for Palaeozoic ammonoids outlined by Korn (2010) and Klug et al. (2015). However, due to the lack of ontogenetic data of some species, some of the descriptions must remain incomplete.

\section{Abbreviations used in the species descriptions}

ah $=$ apertural height

$\mathrm{dm}=$ conch diameter 


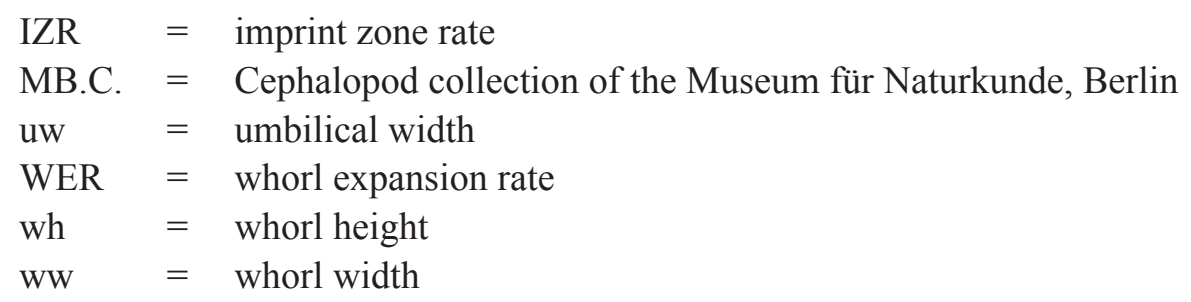

\section{Results}

Order Nautilida Agassiz, 1847

Suborder Tainoceratina Shimansky, 1957

Superfamily Trigonoceratoidea Hyatt, 1884

Family Trigonoceratidae Hyatt, 1884

Genus Maccoyoceras Miller, Dunbar \& Condra, 1933

\section{Type species}

Nautilus (Discites) discors M`Coy, 1844; original designation.

\section{Diagnosis}

Genus of the family Trigonoceratidae with evolute conch; whorls slightly impressed; whorl profile hexagonal or pentagonal with flattened venter and narrowly rounded umbilical margin. Ornament in the adult stage with coarse growth lines, in the preadult stage with fine spiral lines. Suture line with shallow external and lateral lobes. Siphuncle small with subcentral position (after Kummel 1964; emended).

\section{Included species}

Nautilus (Trematodiscus) discoidalis Winchell, 1862, Michigan; Nautilus (Discites) discors M'Coy, 1844, Ireland; Nautilus Leveilleanus de Koninck, 1844, Belgium; Maccoyoceras pentagonum sp. nov., Algeria; Discitoceras wrightii Foord, 1900, Ireland.

\section{Stratigraphic range}

Late Tournaisian to Viséan.

Maccoyoceras pentagonum sp. nov. urn:1sid:zoobank.org:act:5C272A6C-5B23-4D36-B28B-8650C8A6D38B

Figs 2-3; Table 1

\section{Diagnosis}

Species of Maccoyoceras reaching about $80 \mathrm{~mm}$ conch diameter. Conch with weakly compressed to circular whorl profile (ww/wh $=0.80-1.00$ ); venter flattened or completely applanate, ventrolateral shoulder narrowly rounded or subangular. Whorls very weakly embracing or just touching. Ornament in the juvenile stage with spiral lines on the flank and outer area of the venter, in the adult stage without spiral lines. Growth lines with weakly biconvex course with a shallow lateral sinus and a moderately high ventrolateral projection.

\section{Etymology}

From the Latin 'pentagon'; referring to the shape of the whorl profile. 


\section{Type material}

\section{Holotype}

ALGERIA - Gourara, Sebkha de Timimoun $14.5 \mathrm{~km}$ west-southwest of Timimoun; "Dalle à Merocanites" (Tournaisian-Viséan boundary interval); illustrated in Fig. 2A; MB.C.30378.1.

\section{Paratypes}

ALGERIA • 33 specimens; Gourara, Sebkha de Timimoun $14.5 \mathrm{~km}$ west-southwest of Timimoun; "Dalle à Merocanites" (Tournaisian-Viséan boundary interval); MB.C.30378.2- MB.C.30378.34 .

\section{Description}

Holotype MB.C.30378.1 is the largest specimen available; it has a conch almost $74 \mathrm{~mm}$ in diameter (Fig. 2A). It is extremely discoidal and subevolute $(\mathrm{ww} / \mathrm{dm}=0.31 ; \mathrm{uw} / \mathrm{dm}=0.37)$ with compressed whorls $(\mathrm{ww} / \mathrm{wh}=0.80)$ and a very high coiling rate $(\mathrm{WER}=2.65)$. The inner whorls are loosely coiled with a $6 \mathrm{~mm}$ wide umbilical window; the dorsum touches the venter of the previous whorl after one and a quarter whorl. The first whorl and a half are circular in profile. Thereafter, the venter becomes flattened and bordered to the flanks by a subangular shoulder. At $25 \mathrm{~mm}$ in diameter, the umbilical margin becomes narrowly rounded. During the last half whorl, the ventrolateral shoulder becomes rounded and the venter is broadly convex in profile (Fig. 3A).

The ornament shows a succession of four developmental stages in the present specimens:

(1) On slightly more than the first volution, up to a conch diameter of $15 \mathrm{~mm}$, coarse spiral lines and growth lines form a granular surface on the flanks. The growth lines extend backwards on the flank.

(2) For almost three quarters of a whorl between 15 and $28 \mathrm{~mm}$ in diameter, the flanks are ornamented with spiral lines that become strikingly finer during this growth interval. At the beginning of this stage, they are much wider than their interstices, but at the end they are visible as very fine lines separated by interstices ten times wider. Some of the spiral lines granulate out to a diameter of the conch of $23 \mathrm{~mm}$.

(3) A short segment of a volution (between 28 and $32 \mathrm{~mm} \mathrm{dm}$ ) shows hardly visible spiral lines; biconvex, rather coarse growth lines with a weakly biconvex course are the dominant type of ornament.

(4) Beyond $32 \mathrm{~mm}$ diameter of the conch, the ornament consists only of coarse growth lines. They are weakly biconvex with a very low dorsolateral projection, a shallow lateral sinus, a low ventrolateral projection; the venter is almost smooth.

The other specimens illustrated here largely confirm the ornament development of specimen MB.C.30378.1 or provide additional information. Specimen MB.C.30378.4 (Fig. 2D) has a very wellpreserved shell ornament; it clearly shows the sudden change that terminates the second ontogenetic ornament stage at $26 \mathrm{~mm}$ diameter. The third stage with clearly weaker spiral lines is only 45 degrees long.

Specimen MB.C.30378.8 (Fig. 2H) shows, up to at least $40 \mathrm{~mm}$ conch diameter, spiral lines on the venter. Specimen MB.C.30378.5 (Fig. 2E) possesses, between 15 and $20 \mathrm{~mm}$ diameter, rather coarse spiral lines.

Between 20 and $70 \mathrm{~mm}$ shell diameter, there are ontogenetic changes in the shell proportions (Fig. 3BE). These specimens show that the conch becomes more slender (ww/dm decreases from 0.40 to 0.30 ) and slightly more involute (uw/dm decreases from 0.45 to 0.40 ). Additionally, the whorl profile becomes more compressed (ww/wh decreases from 1.10 to 0.80 ). For the first three parameters of the conch, the 

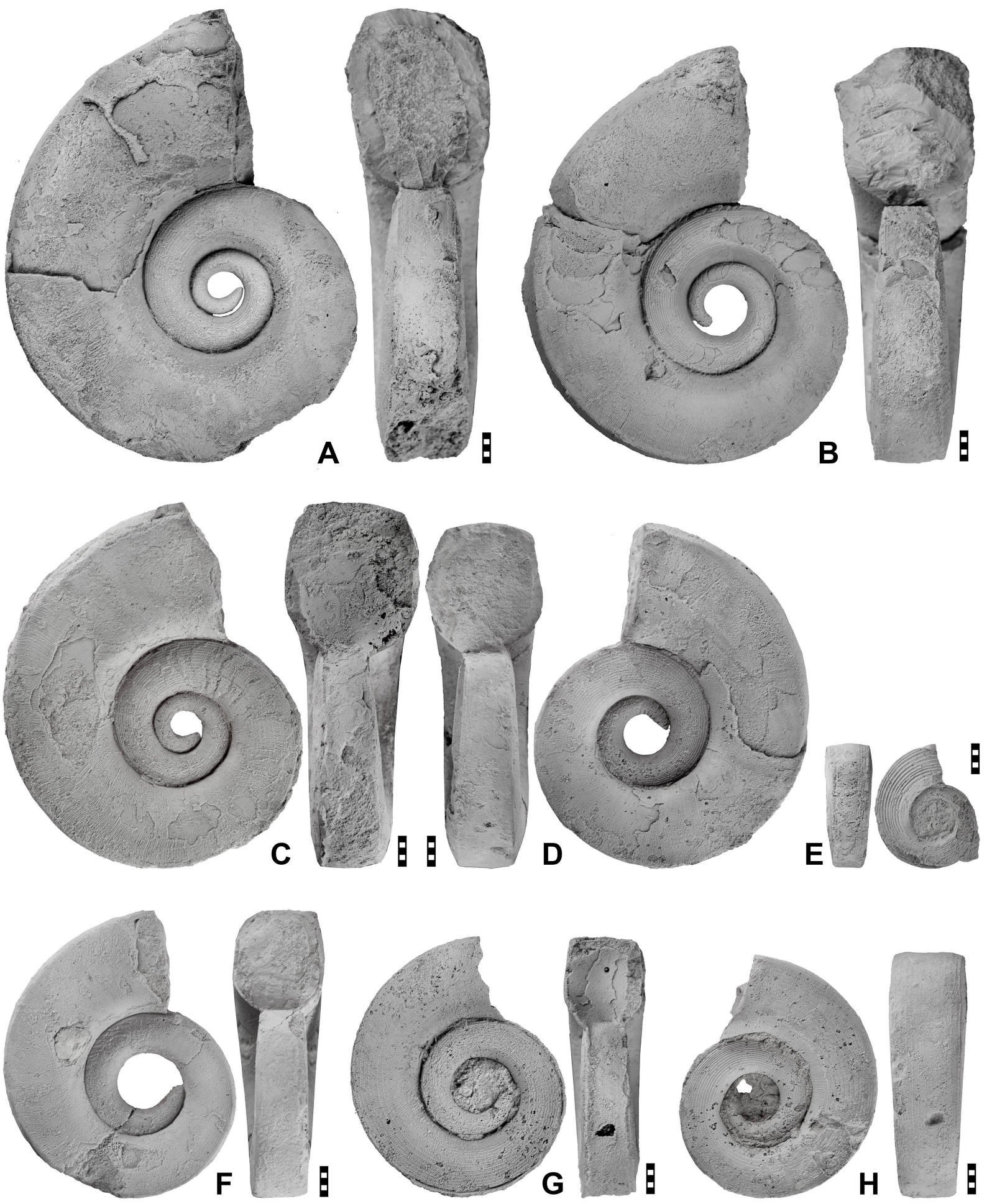

Fig. 2. Maccoyoceras pentagonum sp. nov. A. Holotype MB.C.30378.1. B. Paratype MB.C.30378.2. C. Paratype MB.C.30378.3. D. Paratype MB.C.30378.4. E. Paratype MB.C.30378.5. F. Paratype MB.C.30378.6. G. Paratype MB.C.30378.7. H. Specimen MB.C.30378.8. Scale bar units $=1 \mathrm{~mm}$. 
Table 1. Conch dimensions (in $\mathrm{mm}$ ) and ratios of Maccoyoceras pentagonum sp. nov.

\begin{tabular}{ccccccccccc}
\hline Specimen & $\mathbf{d m}$ & $\mathbf{w w}$ & $\mathbf{w h}$ & $\mathbf{u w}$ & $\mathbf{a h}$ & $\mathbf{w w} / \mathbf{d m}$ & $\mathbf{w w} / \mathbf{w h}$ & $\mathbf{u w} / \mathbf{d m}$ & WER & IZW \\
\hline MB.C.30378.1 & 73.6 & 22.7 & 28.4 & 27.4 & 28.4 & 0.31 & 0.80 & 0.37 & 2.65 & 0.00 \\
MB.C.30378.2 & 62.3 & 20.3 & 21.5 & 26.5 & 21.5 & 0.33 & 0.94 & 0.43 & 2.33 & 0.00 \\
MB.C.30378.3 & 58.8 & 21.0 & 21.8 & 23.4 & 21.8 & 0.36 & 0.96 & 0.40 & 2.53 & 0.00 \\
MB.C.30378.4 & 54.3 & 17.5 & 19.2 & 21.8 & 19.2 & 0.32 & 0.91 & 0.40 & 2.40 & 0.00 \\
MB.C.30378.6 & 47.2 & 14.9 & 16.3 & 20.3 & 16.3 & 0.32 & 0.91 & 0.43 & 2.33 & 0.00 \\
MB.C.30378.7 & 42.4 & 13.3 & 13.5 & 19.5 & 13.5 & 0.31 & 0.99 & 0.46 & 2.15 & 0.00 \\
MB.C.30378.8 & 39.9 & 13.0 & 13.2 & 17.7 & 13.2 & 0.33 & 0.99 & 0.44 & 2.24 & 0.00 \\
MB.C.30378.5 & 20.2 & 7.8 & 6.9 & 8.8 & 6.9 & 0.39 & 1.13 & 0.44 & 2.31 & 0.00 \\
\hline
\end{tabular}

intraspecific variation is small (Fig. 3B-D). In contrast, the plasticity of the coiling rate is very striking; the whorl expansion rate ranges from 2.10 to 2.70 between 30 and $40 \mathrm{~mm}$ conch diameters (Fig. 3E).

\section{Remarks}

Maccoyoceras pentagonum sp. nov. has a similar conch shape and ornament to the other species of the genus already known from Belgium and Ireland. However, the new species differs from M. discors (M'Coy 1844) in the compressed whorl profile, which is approximately quadrate at $80 \mathrm{~mm}$ conch diameter in M. discors. Maccoyoceras leveilleanum has a convex venter (de Koninck 1844) and M. wrightii (Foord, 1900) has a convex venter and an even more compressed whorl profile (ww/wh 0.70 at $50 \mathrm{~mm} \mathrm{dm}$ ) (Foord 1900).
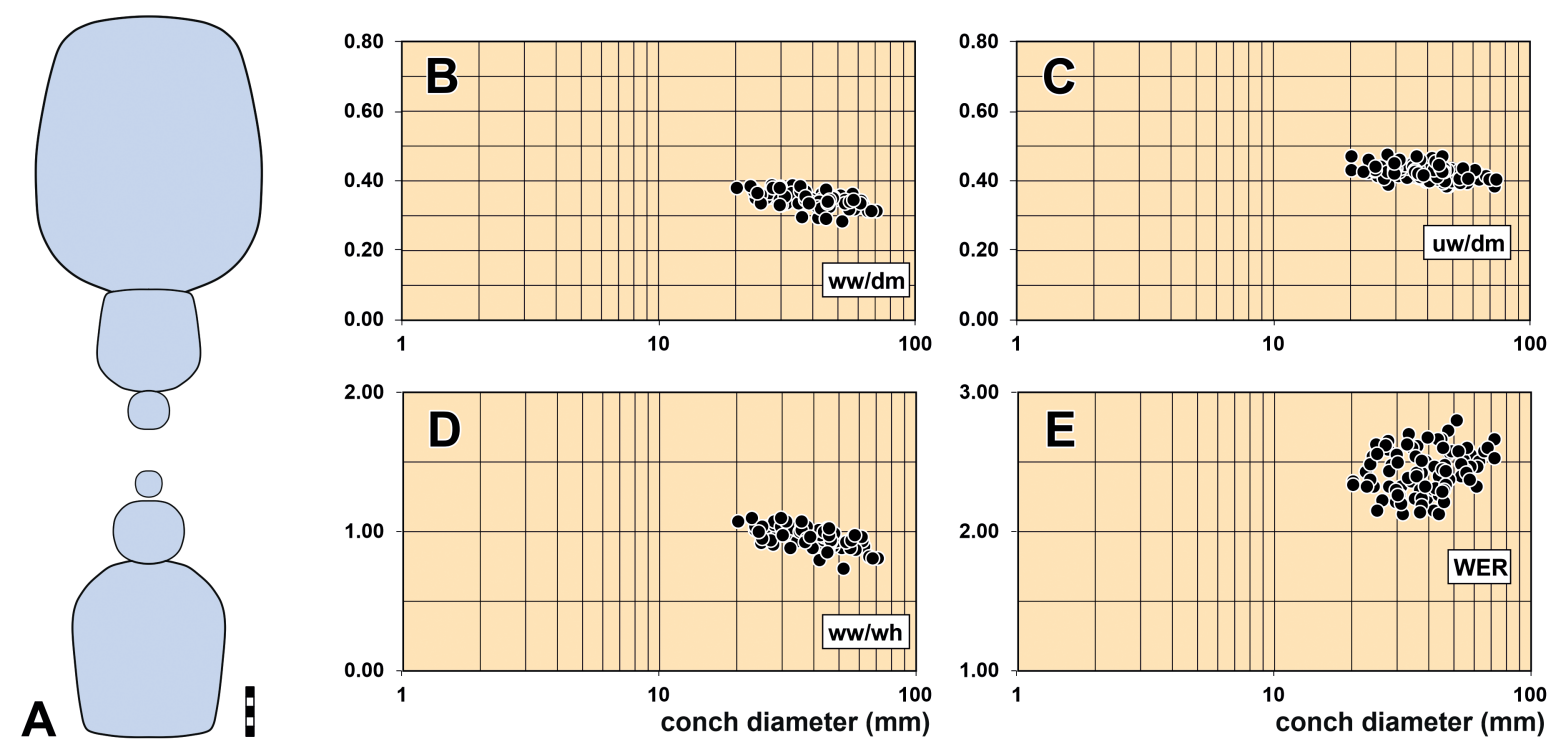

Fig. 3. Maccoyoceras pentagonum sp. nov. A. Reconstructed cross section of the holotype MB.C.30378.1. B-E. Ontogenetic trajectories of the cardinal conch parameters of selected specimens. Scale bar units = $1 \mathrm{~mm}$. 
Genus Lispoceras Hyatt, 1893

\section{Type species}

Lispoceras trivolve Hyatt, 1893; original designation.

\section{Diagnosis}

Genus of the family Trigonoceratidae with evolute conch; whorls just touching each other; whorl profile weakly depressed elliptical or circular. Ornament in the adult stage with fine growth lines, in the preadult stage with fine spiral lines. Suture line with shallow external and lateral lobes. Siphuncle small with subcentral position (after Kummel 1964; emended).

\section{Included species}

Lispoceras orbis sp. nov., Algeria; Lispoceras proconsul Shimansky, 1967, Kazakhstan; Lispoceras rotundum Hyatt, 1893, Ireland; Lispoceras trivolve var. simplum Hyatt, 1893, Belgium; Lispoceras trivolve Hyatt, 1893, Belgium.

\section{Remarks}

Lispoceras was an insufficiently described and delimited genus; the type species $L$. trivolve was described by Hyatt (1893: 426) but not illustrated. Kummel (1964: K430) then published a photographic illustration of the type species and Shimansky (1967: 141) provided a more accurate diagnosis of the genus.

\section{Stratigraphic range}

Late Tournaisian to Viséan.

\section{Lispoceras orbis sp. nov.} urn:lsid:zoobank.org:act:06A766FF-8347-4085-ACB2-39F48B4AD4AE

Figs 4-6; Table 2

\section{Diagnosis}

Species of Lispoceras reaching about $90 \mathrm{~mm}$ conch diameter. Conch with nearly circular whorl profile $(\mathrm{ww} / \mathrm{wh}=1.00-1.10)$. The outer whorl just touches the preceding ones. Ornament in the juvenile stage with spiral lines on the flank and the venter, in the adult stage without spiral lines. Growth lines with weakly biconvex course with a shallow lateral sinus, a moderately high ventrolateral projection and a deep, semicircular ventral sinus.

\section{Etymology}

From the Latin nomen 'orbis', meaning 'circle' and referring to the whorl profile.

\section{Type material}

\section{Holotype}

ALGERIA • Gourara, Sebkha de Timimoun $14.5 \mathrm{~km}$ west-southwest of Timimoun; "Dalle à Merocanites" (Tournaisian-Viséan boundary interval); illustrated in Fig. 4A; MB.C.30379.1.

\section{Paratypes}

ALGERIA • 14 specimens; Gourara, Sebkha de Timimoun 14.5 km west-southwest of Timimoun; "Dalle à Merocanites" (Tournaisian-Viséan boundary interval); MB.C.30379.2- MB.C.30379.15. 


\section{Description}

Holotype MB.C.30379.1 consists of just over two and a half volutions, in which it reaches a conch diameter of $84 \mathrm{~mm}$ (Fig. 4A). Its initial stage is loosely coiled with an $8 \mathrm{~mm}$ wide umbilical window; the poorly preserved protoconch has a circular whorl profile of about $2.5 \mathrm{~mm}$ diameter. The umbilical window is closed at $26 \mathrm{~mm}$ diameter of the conch. The proportions of the conch change only slightly ontogenetically; the whorl profile is circular throughout ontogeny. At a diameter of $84 \mathrm{~mm}$, the conch is thinly discoidal and subevolute $(\mathrm{ww} / \mathrm{dm}=0.42 ; \mathrm{uw} / \mathrm{dm}=0.39)$, with a high coiling rate of the conch $(\mathrm{WER}=2.66)$. Near the maximum diameter of the specimen, the whorl width increases $(\mathrm{ww} / \mathrm{wh}=1.10)$, which may indicate adulthood of the specimen.

The ornament shows a succession of four developmental stages in the present specimens:

(1) The first volution, up to a conch diameter of $18 \mathrm{~mm}$, possesses a combination of coarse spiral lines (about 50 from middorsum to midventer) and growth lines of the same strength. Together, they

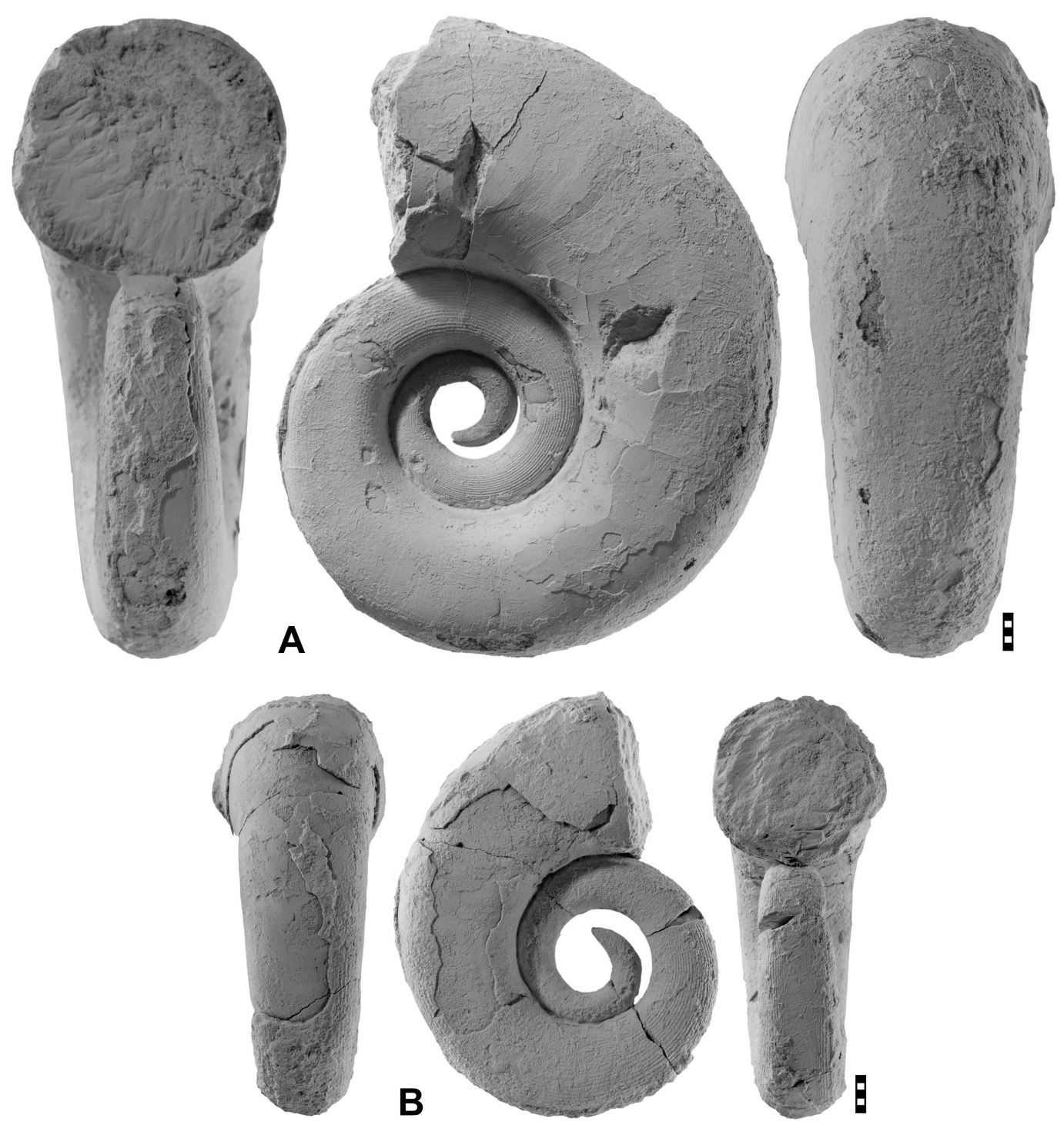

Fig. 4. Lispoceras orbis sp. nov. A. Holotype MB.C.30379.1. B. Paratype MB.C.30379.2. Scale bar units $=1 \mathrm{~mm}$. 
produce a coarse granulation, in which the elements are much wider than their interstices. The growth lines extend backwards on the flank.

(2) In the three quarters of a whorl between 18 and $36 \mathrm{~mm}$ diameter, the ornament is reticulate with a continuous weakening of both the spiral lines and the granulation. At a diameter of $20 \mathrm{~mm}$, the spiral lines are as wide as their interspaces, but at $36 \mathrm{~mm}$ diameter, the interspaces are already five times as wide as the spiral lines. The growth line course is rectiradiate and weakly biconvex.

(3) In a quarter of a volution (between 36 and $44 \mathrm{~mm} \mathrm{dm}$ ), the spiral lines are very weak; the growth lines are also weaker when compared with the preceding stage.

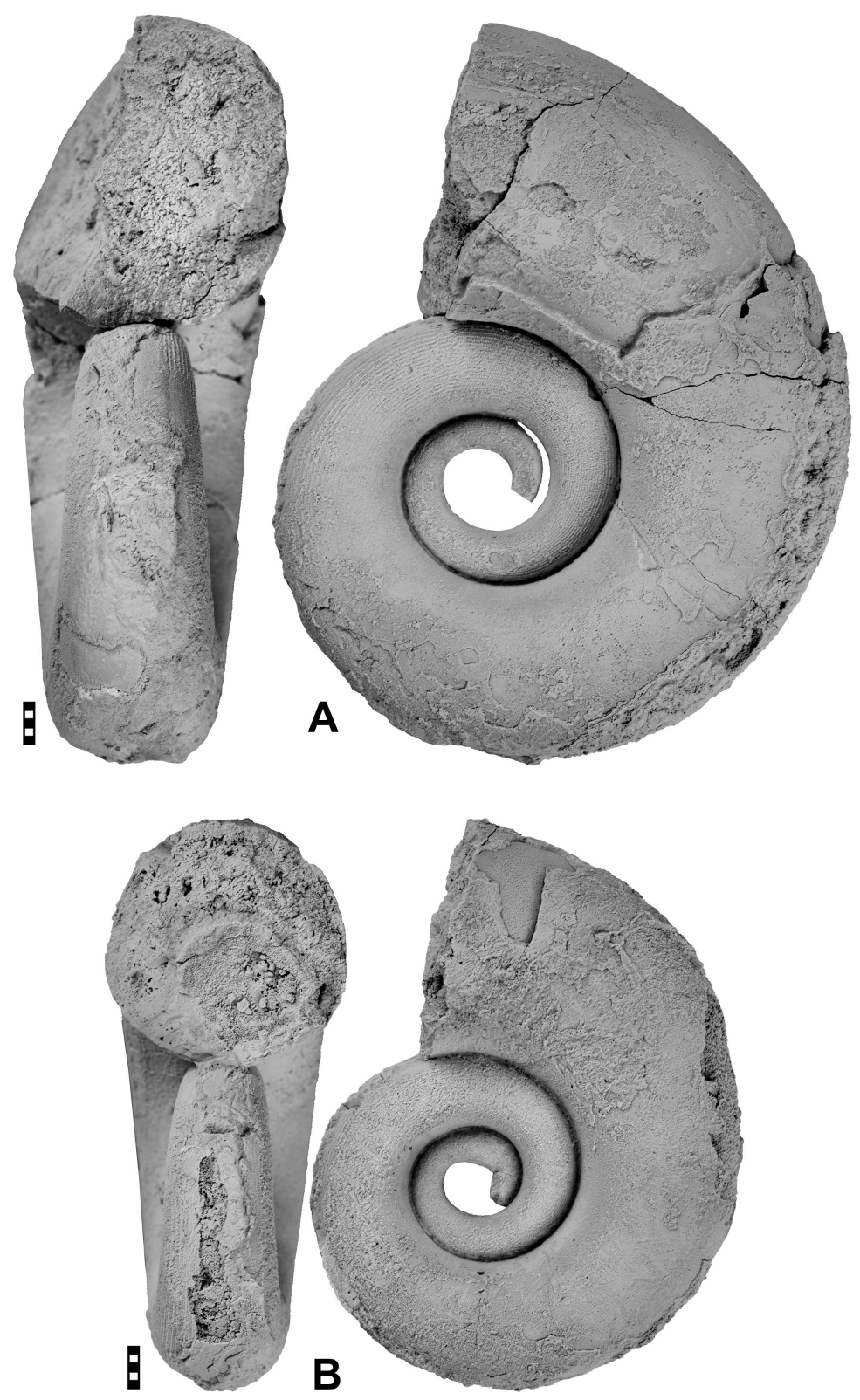

Fig. 5. Lispoceras orbis sp. nov. A. Paratype MB.C.30379.3. B. Paratype MB.C.30379.4. Scale bar units $=1 \mathrm{~mm}$. 
Table 2. Conch dimensions (in $\mathrm{mm}$ ) and ratios of Lispoceras orbis sp. nov.

\begin{tabular}{ccccccccccc}
\hline Specimen & dm & ww & wh & uw & ah & ww/dm & ww/wh & uw/dm & WER & IZW \\
\hline MB.C.30379.1 & 83.6 & 35.5 & 32.3 & 33.0 & 32.3 & 0.42 & 1.10 & 0.39 & 2.66 & 0.00 \\
MB.C.30379.3 & 72.5 & 29.2 & 28.4 & 27.4 & 28.4 & 0.40 & 1.03 & 0.38 & 2.70 & 0.00 \\
MB.C.30379.4 & 65.7 & 27.6 & 27.0 & 24.4 & 26.0 & 0.42 & 1.02 & 0.37 & 2.73 & 0.04 \\
MB.C.30379.2 & 55.0 & 21.0 & 21.4 & 21.5 & 21.4 & 0.38 & 0.99 & 0.39 & 2.67 & 0.00 \\
\hline
\end{tabular}

(4) The last stage above $44 \mathrm{~mm}$ conch diameter is then characterised by the loss of the spiral lines. Very fine growth lines extend across the flank in a weakly biconvex course, forming a deep, semicircular ventral sinus.

Intraspecific variation is limited in the material (Fig. 6B-E), but the cardinal conch parameters show some ontogenetic changes in the growth interval between 20 and $85 \mathrm{~mm}$ conch diameter: (1) the ww/ $\mathrm{dm}$ ratio increases slowly from an average of 0.38 to 0.42 (Fig. 6B), (2) the uw/dm ratio decreases from nearly 0.50 to 0.38 (Fig. 6C), (3) the ww/wh ratio decreases from 1.20 to 1.00 (Fig. 6D) and (4) the whorl expansion rate shows a more prominent increase from 2.20 to 2.80 (Fig. 6E).

Variation in the ornament is also limited. The change from the third to the fourth ornament stage, for instance, takes place between 37 and $42 \mathrm{~mm}$ conch diameter in specimens MB.C.30379.4 (Fig. 5B), MB.C.30379.2 (Fig. 4B) and MB.C.30379.3 (Fig. 5A).
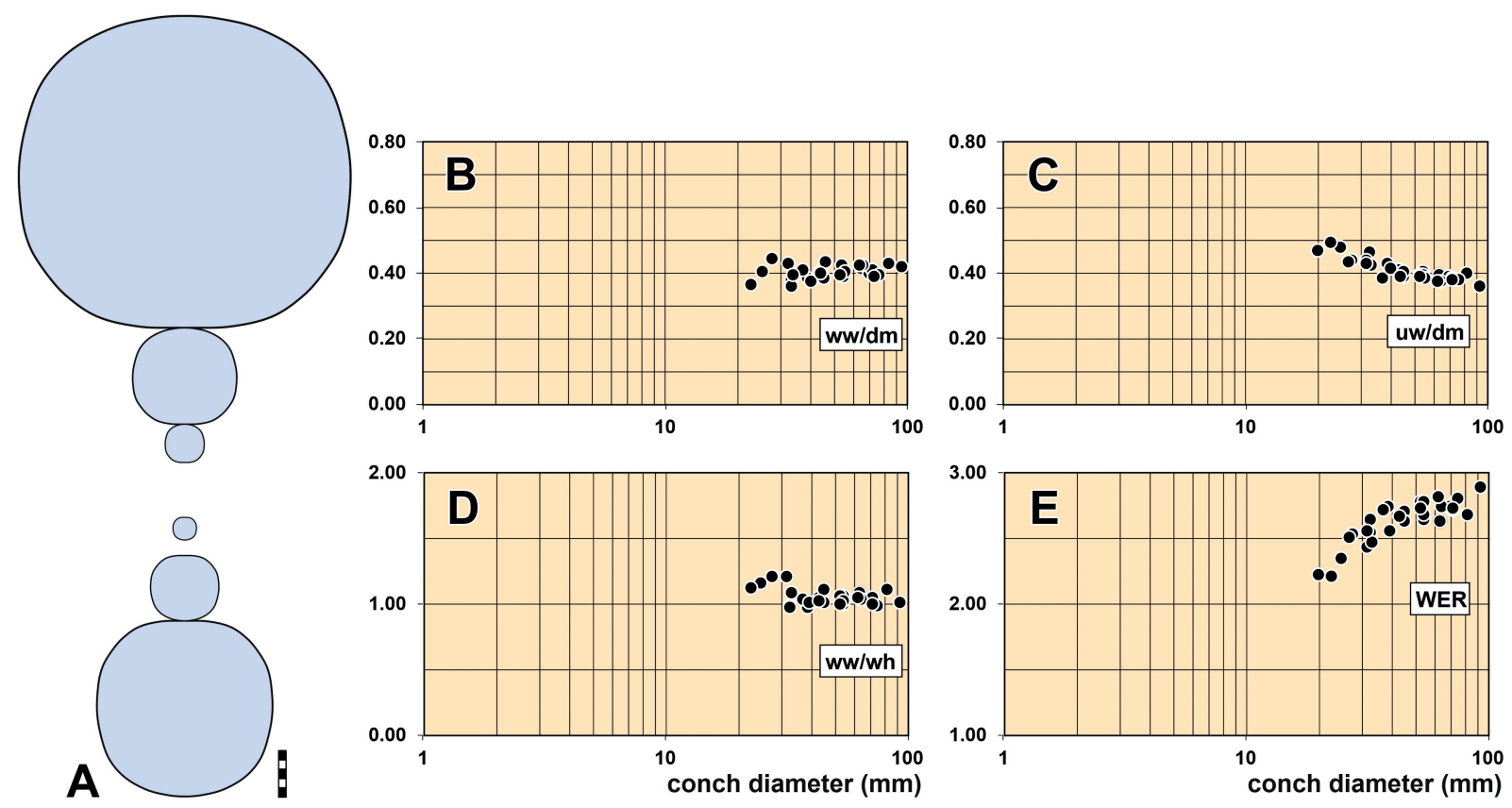

Fig. 6. Lispoceras orbis sp. nov. A. Reconstructed cross section of holotype MB.C.30379.1. B-E. Ontogenetic trajectories of the cardinal conch parameters of selected specimens. Scale bar units = $1 \mathrm{~mm}$. 


\section{Remarks}

Lispoceras orbis sp. nov. has a circular to very weakly depressed whorl profile (ww/wh $=1.00-1.10)$ and thus differs from $L$. trivolve with a slightly more depressed whorl profile (ww/wh $=1.25)$. In addition, L. trivolve has much coarser spiral lines (Kummel 1964). L. proconsul also has more depressed whorl profile $(\mathrm{ww} / \mathrm{wh}=1.05-1.25)$ and whorls that detach from the previous whorl at about $30 \mathrm{~mm}$ diameter of the conch (Shimansky 1967).

Genus Thrincoceras Hyatt, 1893

\section{Type species}

Thrincoceras depressum Hyatt, 1893; subsequent designation by Schmidt (1951).

\section{Diagnosis}

Genus of the family Trigonoceratidae with evolute conch; whorls slightly impressed or slightly detached; whorl profile nearly quadrate with flattened venter and narrowly rounded ventrolateral shoulder and umbilical margin. Ornament with fine growth lines and moderately coarse spiral lines. Suture line with shallow external and lateral lobes. Siphuncle small with subcentral position (after Kummel 1964; emended).

\section{Included species}

Thrincoceras depressum Hyatt, 1893, Kentucky; Gyroceras Hibernicum Foord, 1891, Ireland; Thrincoceras Hyatti Foord, 1900, Ireland; Thrincoceras kentuckiense Hyatt, 1893, Kentucky; Thrincoceras devolvere sp. nov., Algeria.

\section{Remarks}

Several genera with a coarse spiral ornament and granulation on the spirals were introduced within the family Trigonoceratidae; these show a rather continuous morphological variation:

Chouteauceras Miller \& Garner, 1953 - whorls compressed, oval, separated by interspaces;

Rineceras Hyatt, 1893 - whorls depressed, oval or rounded triangular, separated by interspaces;

Pararineceras Turner, 1954 - whorls depressed, oval or rounded triangular to rounded-trapezoidal, touching or slightly embracing the preceding one;

Discitoceras Hyatt, 1884 - whorls depressed, subtrapezoidal with narrowly rounded venter, slightly embracing the preceding one;

Thrincoceras Hyatt, 1893 - whorls subquadrate in section and embracing the preceding one. However, one must bear in mind that Thrincoceras also developed an adult stage in which the whorl loses contact with the preceding one. The holotype of $T$. hyatti, for instance, uncoils at about $90 \mathrm{~mm}$ conch diameter (Foord 1900; Histon 1999).

\section{Stratigraphic range}

Late Tournaisian to Late Carboniferous (?).

Thrincoceras devolvere sp. nov.

urn:lsid:zoobank.org:act:DFAFE2FC-2688-426E-B543-D0F61D31C354

Fig. 7; Table 3

\section{Diagnosis}

Species of Thrincoceras with weakly depressed, rounded-trapezoidal whorl profile (ww/wh 1.40), venter slightly flattened, ventrolateral shoulder broadly rounded. Whorls slightly embracing, above 
$40 \mathrm{~mm} \mathrm{dm}$ with the tendency for slow uncoiling. Ornament with about 20 spiral lines on the flank and few delicate spiral lines on the outer part of the venter, main area of the venter without spiral lines. Growth lines concavo-convex with shallow lateral sinus and deep, rounded V-shaped ventral sinus.

\section{Etymology}

After the Latin verb 'devolvere', meaning 'devolve', referring to the coiling.

\section{Type material}

\section{Holotype}

ALGERIA • Gourara, Sebkha de Timimoun 14.5 km west-southwest of Timimoun; "Dalle à Merocanites" (Tournaisian-Viséan boundary interval); illustrated in Fig. 7; MB.C.30380.

\section{Description}

Holotype MB.C.30380 is an incomplete specimen with $43 \mathrm{~mm}$ diameter of the conch (Fig. 7). It is thinly discoidal and evolute $(\mathrm{ww} / \mathrm{dm}=0.44 ; \mathrm{uw} / \mathrm{dm}=0.48)$, with a weakly depressed, rounded-trapezoidal whorl profile $(\mathrm{ww} / \mathrm{wh}=1.37)$ and a high coiling rate $(\mathrm{WER}=2.14)$. It can be seen on the specimen that uncoiling starts at the last quarter of the last whorl, as the depth of the imprint zone decreases slightly.

The ornament consists of about 20 spiral lines on the flank, which are raised to faint ridges in the region of the middle flank and become weaker towards both the umbilicus and the venter. These spirals are crossed by finer growth lines and together form a conspicuous granulation on the penultimate volution. Most part of the venter does not have spiral lines; there are delicate growth lines, which form a deep and wide, rounded V-shaped ventral sinus. It appears that one volution earlier, spirals are also developed on the venter, but the specimen is poorly preserved in this area.

\section{Remarks}

Thrincoceras devolvere sp. nov. differs from the two North American species T. kentuckiense and T. depressum first in the size of the conch, which in the two latter species reaches well over $100 \mathrm{~mm}$ (Hyatt 1893). T. kentuckiense, however, has a very similar whorl profile to T. devolvere sp. nov., but shows no detachment of the whorls from the preceding one.

The species known from Ireland, T. hyatti and T. hibernicum, have more subangular ventrolateral shoulders and flattened flanks (Foord 1891, 1900) and therefore differ in whorl profile from T. devolvere sp. nov.

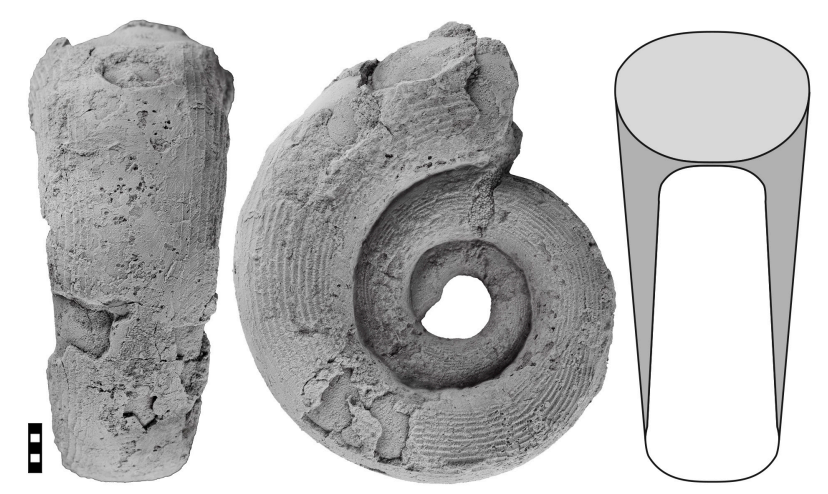

Fig. 7. Thrincoceras devolvere sp. nov., holotype MB.C.30380. Scale bar units $=1 \mathrm{~mm}$. 
Table 3. Conch dimensions (in $\mathrm{mm}$ ) and ratios of Thrincoceras devolvere sp. nov.

\begin{tabular}{ccccccccccc}
\hline Specimen & dm & ww & wh & uw & ah & ww/dm & ww/wh & uw/dm & WER & IZW \\
\hline MB.C.30380 & 43.2 & 18.8 & 13.7 & 20.9 & 13.7 & 0.44 & 1.37 & 0.48 & 2.14 & 0.00 \\
\hline
\end{tabular}

Genus Rineceras Hyatt, 1893

\section{Type species}

Gyroceras propinquum de Koninck, 1880; subsequent designation by Foord (1900).

\section{Diagnosis}

Genus of the family Trigonoceratidae with evolute conch; whorls detached or slightly in contact; whorl profile elliptical or rounded triangular with broad venter. Ornament with coarse growth lines and coarse spiral ridges; coarse granulation at the crossing points of growth lines and spiral ridges. Suture line with shallow external and lateral lobes. Siphuncle small with subcentral position (after Kummel 1964; emended).

\section{Included Early Carboniferous species}

Rhineceras alapaevskensis Kruglov, 1934, Urals; Pararineceras balladoolense Turner, 1954, Isle of Man; Nautilus canaliculatus von Eichwald, 1857, south Urals; Rineceras carinatiforme Shimansky, 1967, Kazakhstan; Nautilus carinatus von Eichwald, 1857, western Russia; Nautilus (Discus) digonus Meek \& Worthen, 1860, Indiana; Nautilus Luidii Fleming, 1828, Derbyshire; Nautilus (Trematodiscus) Meekianus Winchell, 1862, Michigan; Gyroceras Meyerianum de Koninck, 1844, Belgium; Rineceras multituberculatum sp. nov., Algeria; Rineceras ohioense Miller \& Garner, 1953, Ohio; Triboloceras patteiskyi Schmidt, 1951, Rhenish Mountains; Gyroceras propinquum de Koninck, 1880, Belgium; Rineceras rectangulatum sp. nov., Algeria; Nautilus rhenanus Holzapfel, 1889, Rhenish Mountains; Nautilus (Trematodiscus) strigatus Winchell, 1862, Michigan.

\section{Remarks}

Turner (1954) introduced the genus Pararineceras on the basis of the species originally described by Martin $(1793,1809)$ as "Conchyliolithus N. Ammonites (Luidii)", but as Martin did not follow the Linnaean binomial procedure, Fleming (1828) is regarded as the author of the species (Turner 1953). This species differs from most of the species assigned to the genus Rineceras only by the more densely coiled conch, a character that might be gradual and not useful for a separation of genera. While Kummel (1964) accepted both of the two genera, Shimansky (1967) and Dzik (1984) regarded Pararineceras as a synonym of Rineceras. In the following, we treat Pararineceras a junior synonym of Rineceras until a clear separation can be demonstrated.

\section{Stratigraphic range}

Middle Tournaisian to Serpukhovian.

Rineceras multituberculatum sp. nov. urn:1sid:zoobank.org:act:B0489DAA-C8AB-4809-92D3-6F3120899BBD

Fig. 8; Table 4

\section{Etymology}

After the Latin 'multi', meaning 'many', and 'tuberculum', meaning 'tubercle' and referring to the shell ornament. 
Table 4. Conch dimensions (in $\mathrm{mm}$ ) and ratios of Rineceras multituberculatum sp. nov.

\begin{tabular}{ccccccccccc}
\hline Specimen & dm & ww & wh & uw & ah & ww/dm & ww/wh & uw/dm & WER & IZW \\
\hline MB.C.30381 & 21.3 & 9.9 & 6.9 & 9.7 & 6.2 & 0.47 & 1.45 & 0.45 & 1.99 & 0.09 \\
\hline
\end{tabular}

\section{Type material}

\section{Holotype}

ALGERIA • Gourara, Sebkha de Timimoun 14.5 km west-southwest of Timimoun; "Dalle à Merocanites" (Tournaisian-Viséan boundary interval); illustrated in Fig. 8; MB.C.30381.

\section{Diagnosis}

Species of Rineceras with weakly depressed, rounded-trapezoidal whorl profile (ww/wh $\sim 1.45$ ), venter slightly flattened, ventrolateral shoulder broadly rounded. Whorls slightly embracing. Ornament with about 25 spiral lines on the flank and the venter.

\section{Description}

Holotype MB.C.30381 has a conch diameter of $21 \mathrm{~mm}$ (Fig. 8), with a depressed, rounded-trapezoidal whorl profile $(\mathrm{ww} / \mathrm{wh}=1.44)$ with a flattened venter and a broadly rounded ventrolateral shoulder. The whorl embraces the preceding only a very little. The well-preserved ornament consists of about 20 (from umbilicus to midventer) coarse spiral lines with a coarse granulation at the points of intersection with the growth lines. The spiral lines are equally coarse on the flanks and the venter.

\section{Remarks}

With its rounded trapezoidal whorl profile, Rineceras multituberculatum sp. nov. differs from species such as R. propinquum (de Koninck, 1880), R. carinatum (von Eichwald, 1857), R. alapaevskense and $R$. ohioense, which are loosely coiled and have either a rounded triangular, or an oval whorl profile (Koninck 1880; Miller \& Garner 1953; Shimansky 1967). In this respect, R. multituberculatum sp. nov. and R. meekianum (Winchell, 1862) are similar (Winchell 1862), but have only weak spiral lines on the venter. Rineceras canaliculatum (von Eichwald, 1857) has a whorl profile similar to $R$. multituberculatum sp. nov., but much coarser spiral lines on the flank (Shimansky 1967).

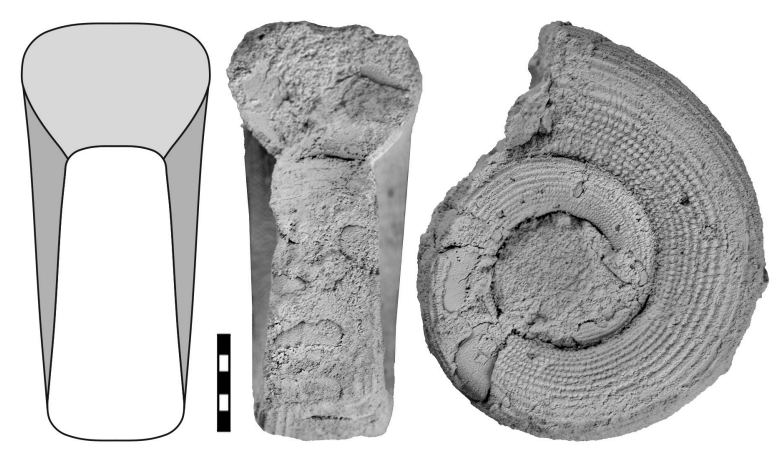

Fig. 8. Rineceras multituberculatum sp. nov., holotype MB.C.30381. Scale bar units $=1 \mathrm{~mm}$. 


\section{Rineceras rectangulatum $\mathrm{sp}$. nov. urn:1sid:zoobank.org:act:B6626858-751D-4EA3-B80C-76D5D11CAAC7}

Fig. 9; Table 5

\section{Etymology}

Referring to the rectangular ventrolateral shoulder.

\section{Type material}

\section{Holotype}

ALGERIA • Gourara, Sebkha de Timimoun $14.5 \mathrm{~km}$ west-southwest of Timimoun; "Dalle à Merocanites" (Tournaisian-Viséan boundary interval); illustrated in Fig. 9, MB.C.30382.

\section{Diagnosis}

Species of Rineceras with weakly depressed, rounded-trapezoidal whorl profile (ww/wh 1.45), venter flattened, umbilical shoulder broadly rounded without clean boundary between the flank and the umbilical wall. Whorls slightly embracing. Ornament in the juvenile stage with weak spiral lines on the flank.

\section{Description}

Holotype MB.C.30382 is an incomplete specimen with $50 \mathrm{~mm}$ diameter (Fig. 9). A little more than a quarter whorl belongs to the body chamber. The conch is thickly discoidal and subevolute $(\mathrm{ww} / \mathrm{dm}=$ $0.57 ; \mathrm{uw} / \mathrm{dm}=0.42$ ) with a flat venter and an angular ventrolateral shoulder. The flanks are very slightly concave and diverge slowly towards the venter; the umbilical margin and the umbilical wall are broadly rounded. The penultimate volution differs in its oval whorl profile and the wider umbilicus (uw/dm = 0.50 at $24 \mathrm{~mm} \mathrm{dm}$ ). The umbilical window has a width of approximately $6 \mathrm{~mm}$.

Most of the specimen is exfoliated and corroded, but the penultimate whorl shows about five spiral ridges on the flanks. Traces of these ridges are still visible on the last preserved volution. The suture line has a broadly V-shaped external lobe with rounded base on the venter, a shallow lobe on the flank and an incipient lobe on the umbilical wall.

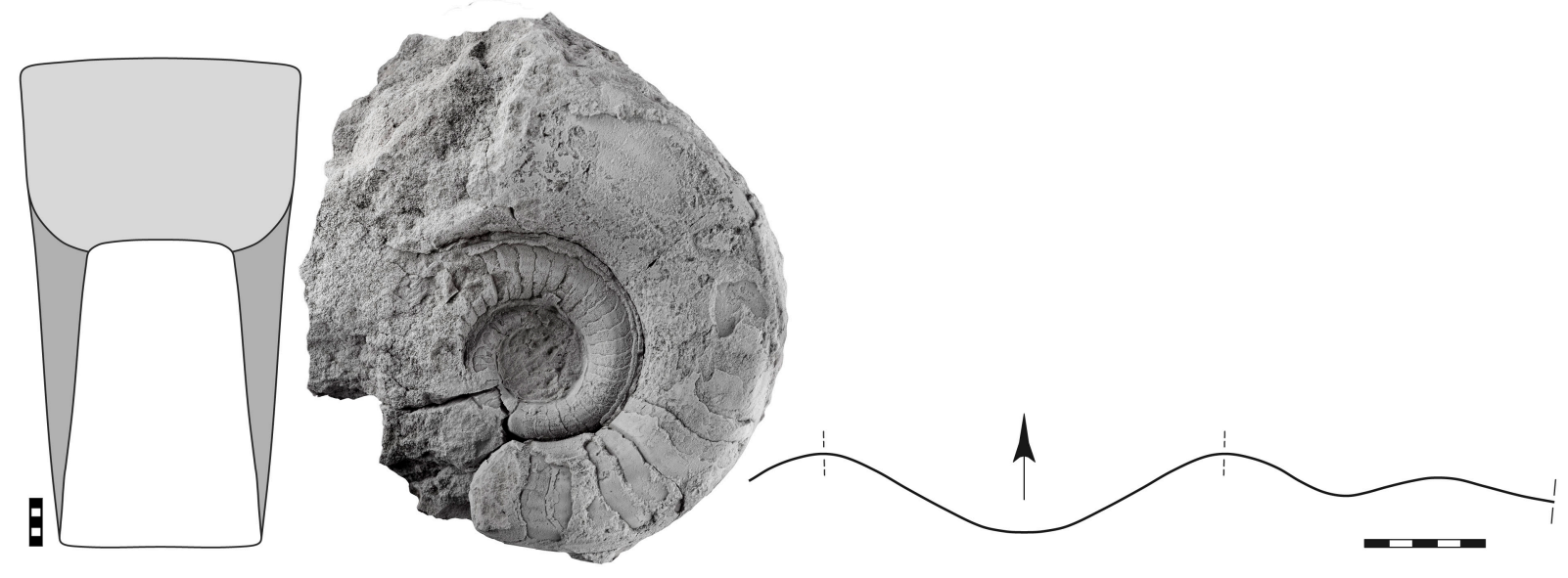

Fig. 9. Rineceras rectangulatum sp. nov., dorsal view reconstruction, lateral view and suture line (at $36 \mathrm{~mm} \mathrm{dm}, 21 \mathrm{~mm} w w, 14 \mathrm{~mm}$ wh) of holotype MB.C.30382. Scale bar units $=1 \mathrm{~mm}$. 
Table 5. Conch dimensions (in $\mathrm{mm}$ ) and ratios of Rineceras rectangulatum sp. nov.

\begin{tabular}{ccccccccccc}
\hline Specimen & dm & ww & wh & uw & ah & ww/dm & ww/wh & uw/dm & WER & IZW \\
\hline MB.C.30382 & 50.7 & 29.0 & 20.1 & 21.2 & 18.9 & 0.57 & 1.44 & 0.42 & 2.54 & 0.06 \\
\hline
\end{tabular}

\section{Remarks}

Rineceras rectangulatum sp. nov. differs from most species of the genus by the trapezoidal whorl profile with angular ventrolateral shoulder. Rineceras carinatiforme has a similar shape, but in this species the venter is broadly rounded here and not perfectly flat as in $R$. rectangulatum $\mathrm{sp}$. nov. Rineceras strigatum (Winchell, 1862) is also similar, but shows a sharp ventrolateral shoulder (Shimansky 1967).

Genus Vestinautilus Ryckholt, 1852

\section{Type species}

Nautilus Koninckii d’Orbigny, 1850; subsequent designation by Hyatt (1883-1884).

\section{Diagnosis}

Genus of the family Trigonoceratidae with evolute conch; whorls slightly impressed; whorl profile rounded triangular or trapezoidal with flattened or weakly concave venter and pronounced ventrolateral shoulder. Ornament with fine lines and very coarse spiral ridges around the ventrolateral shoulder, sometimes also on the venter. Suture line slightly sinuous. Siphuncle small with subcentral position (after Kummel 1964; emended).

\section{Included species}

Nautilus (Trematodiscus) altidorsalis Winchell, 1862, Michigan; Nautilus biangulatus Sowerby, 1825, Southwest England; Nautilus cariniferus Sowerby, 1825, Ireland; Vestinautilus concinnus sp. nov. Algeria; Triboloceras formosum Foord, 1900, Ireland; Nautilus Koninckii d'Orbigny, 1850, Belgium; Nautilus multicarinatus Sowerby, 1825, Ireland; Vestinautilus padus sp. nov., Algeria; Coelonautilus paucicarinatus Foord, 1891, Ireland; Nautilus pinguis de Koninck, 1844, Belgium; Vestinautilus semiglaber Foord, 1900, Ireland; Vestinautilus semiplicatus Foord, 1900, Ireland.

\section{Remarks}

When Turner (1954) revised the genus Vestinautilus, he explicitly restricted the genus "to forms resembling the type species in possessing a venter concave or channelled at some stage of growth, a broad, depressed whorl profile, and a conch ornamented with spiral ribs, lirae and sulci." At the same time, he introduced the new genus Subvestinautilus, which he placed in the family Temnocheilidae Mojsisovics, 1902. He stated that "the genus much resembles Vestinautilus ... in shape but lacks a concave or channelled venter at any stage of development." However, since he regarded Vestinautilus as belonging to the family Triboloceratidae Hyatt, 1884, he indirectly regarded the close morphological similarity as a result of convergent evolution. This opinion was followed (albeit with other family names) by Shimansky (1967) and Histon (1999), but rejected by Dzik (1984), who treated Subvestinautilus as a synonym of Vestinautilus.

Here, we accept the separation of the two genera, but not the restrictive practice of Turner (1954), who considered the ventral shape (concave or convex) as the distinguishing character. The rather variable shape of the venter, which often changes throughout ontogeny in some of the species, can hardly be regarded as a criterion for distinguishing between the two families. We therefore assign those species 
with coarse spiral ridges and a broad trapezoidal whorl profile, whether they possess a concave or convex venter, to Vestinautilus.

\section{Stratigraphic range}

Late Tournaisian to Viséan.

Vestinautilus padus sp. nov. urn:1sid:zoobank.org:act:9743A462-BB55-45D0-9BA6-1C1AB43DE9DC

Fig. 10; Table 6

\section{Etymology}

After the Latin nomen 'padus', meaning 'twine, yarn' and referring to the conch shape like a yarn reel.

\section{Type material}

\section{Holotype}

ALGERIA • Gourara, Sebkha de Timimoun 14.5 km west-southwest of Timimoun; "Dalle à Merocanites" (Tournaisian-Viséan boundary interval); illustrated in Fig. 10; MB.C.30383.

\section{Diagnosis}

Species of Vestinautilus with strongly depressed, rounded-trapezoidal whorl profile (ww/wh $~ 2.10$ ), venter broadly arched, ventrolateral shoulder defined by an angular margin produced by a broad ridge. A second, sharper ridge is located on the umbilical wall near the ventrolateral shoulder. Whorls weakly embracing, coiling very high (WER 2.55). Ornament with delicate growth lines.

\section{Description}

Holotype MB.C.30383 is a rather well-preserved specimen with a diameter of $34 \mathrm{~mm}$ (Fig. 10). It is a subevolute conch $(\mathrm{ww} / \mathrm{dm}=0.90 ; \mathrm{uw} / \mathrm{dm}=0.33)$ with a very high coiling rate $(\mathrm{WER}=2.57)$. The diameter of the umbilical window is about $5 \mathrm{~mm}$. The whorl profile is strongly depressed $(\mathrm{ww} / \mathrm{wh}=$ 2.11) and rounded-trapezoidal in outline with a broadly arched venter. The flanks and the venter are fused together; they are separated from the convex umbilical wall by two longitudinal ridges, which are separated by a shallow longitudinal groove. While the outer of the two ridges is subangular in cross section, the inner one is sharp and probably raised only by shell material. The shell ornament consists of delicate growth lines, which are reinforced on the inner longitudinal ridge.
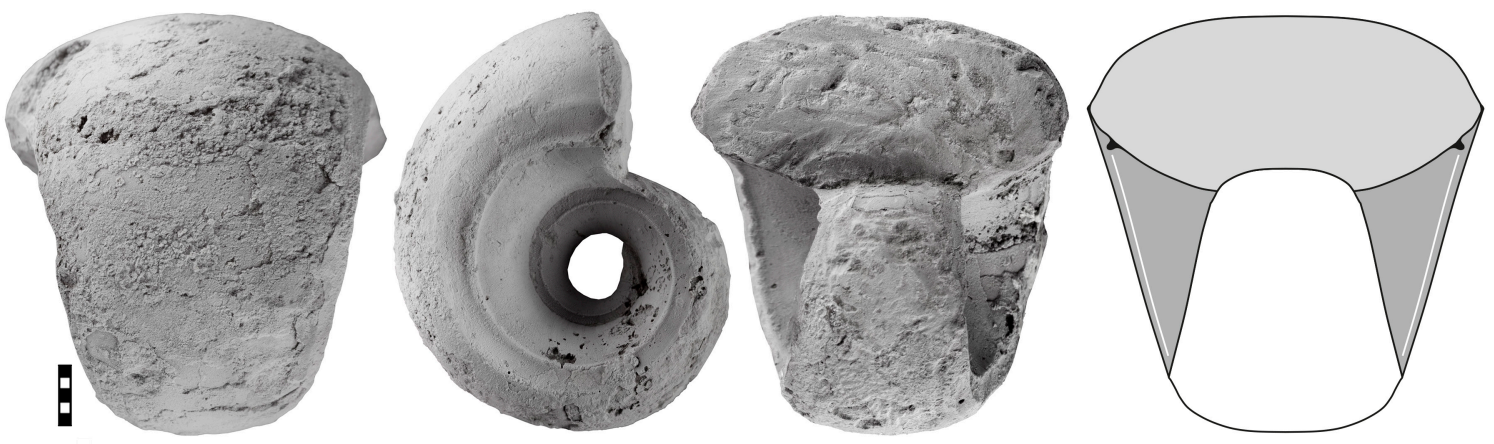

Fig. 10. Vestinautilus padus sp. nov., holotype MB.C.30383. Scale bar units $=1 \mathrm{~mm}$. 
Table 6. Conch dimensions (in $\mathrm{mm}$ ) and ratios of Vestinautilus padus sp. nov.

\begin{tabular}{ccccccccccc}
\hline Specimen & $\mathbf{d m}$ & ww & wh & uw & ah & ww/dm & ww/wh & uw/dm & WER & IZW \\
\hline MB.C.30383 & 33.5 & 30.2 & 14.3 & 11.1 & 12.6 & 0.90 & 2.11 & 0.33 & 2.57 & 0.12 \\
\hline
\end{tabular}

\section{Remarks}

Vestinautilus padus sp. nov. belongs to the species of the genus that possess a very broad whorl profile $(\mathrm{ww} / \mathrm{wh}>2.00)$ and an ornament with only a few spiral ridges. In this respect, $V$. cariniformis (Sowerby, 1825), V. paucicarinatus (Foord, 1891), V. pinguis (de Koninck, 1844) and V. semiplicatus are similar, but these four species have a concave venter at least in some phases in ontogeny (Sowerby 1825; de Koninck 1844; Foord 1891, 1900). Subvestinautilus crassimarginatus (Foord, 1900) and S. crateriformis (Foord, 1900) have a convex venter in all stages (Foord 1900), but they do not have the spiral ridges that are characteristic for $V$. padus sp. nov.

Vestinautilus concinnus sp. nov.

urn:1sid:zoobank.org:act:B1F94168-8870-4D86-9220-ADC18E85D2AB

Fig. 11; Table 7

\section{Etymology}

After the Latin 'concinnus', meaning 'harmonic, elegant' and referring to the ornament.

\section{Type material}

\section{Holotype}

ALGERIA • Gourara, Sebkha de Timimoun $14.5 \mathrm{~km}$ west-southwest of Timimoun; "Dalle à Merocanites" (Tournaisian-Viséan boundary interval); illustrated in Fig. 11; MB.C.30384.

\section{Diagnosis}

Species of Vestinautilus with weakly depressed, trapezoidal whorl profile (ww/wh 1.45), venter flattened, ventrolateral shoulder defined by an angular margin produced by a distinct ridge. Another four sharp ridges are located on the outer umbilical wall and two on the outer ventral area. Whorls weakly embracing. Ornament with sharp growth lines on the flank, producing elongate granulation when crossing the spiral ridges; growth lines delicate on the venter forming a deep sinus.

\section{Description}

Holotype MB.C.30384 is an incomplete specimen $32 \mathrm{~mm}$ in diameter (Fig. 11). It is a thickly discoidal, subevolute conch $(\mathrm{ww} / \mathrm{dm} \sim 0.50 ; \mathrm{uw} / \mathrm{dm} \sim 0.45)$ with a weakly depressed whorl profile $(\mathrm{ww} / \mathrm{wh} \sim$ 1.45). The whorl profile is subtrapezoidal with a broadly rounded umbilical wall, flattened and weakly converging flanks, a narrowly rounded ventrolateral shoulder and an almost flat venter. The flanks and the marginal part of the venter bear seven ridges. The interspace between the $4^{\text {th }}$ and the $5^{\text {th }}$ ridges is deepened to a longitudinal groove. The shell ornament consists of sharp, biconvex growth lines, which are coarsest on the flank; they are even coarser and produce a granulation when crossing the ridges. The suture line is only visible in some parts; broadly rounded ventral and lateral lobes are visible.

\section{Remarks}

Vestinautilus concinnus sp. nov. belongs to the species of the genus with a rather slender conch and hence a rather low ratio of whorl width and whorl height; therefore, the new species is easily distinguishable 
Table 7. Conch dimensions (partly estimated; in $\mathrm{mm}$ ) and ratios of Vestinautilus concinnus sp. nov.

\begin{tabular}{ccccccccccc}
\hline Specimen & dm & ww & wh & uw & ah & ww/dm & ww/wh & uw/dm & WER & IZW \\
\hline MB.C.30384 & 32.1 & 16.0 & 11.1 & 14.3 & 10.7 & 0.50 & 1.44 & 0.45 & 2.25 & 0.04 \\
\hline
\end{tabular}
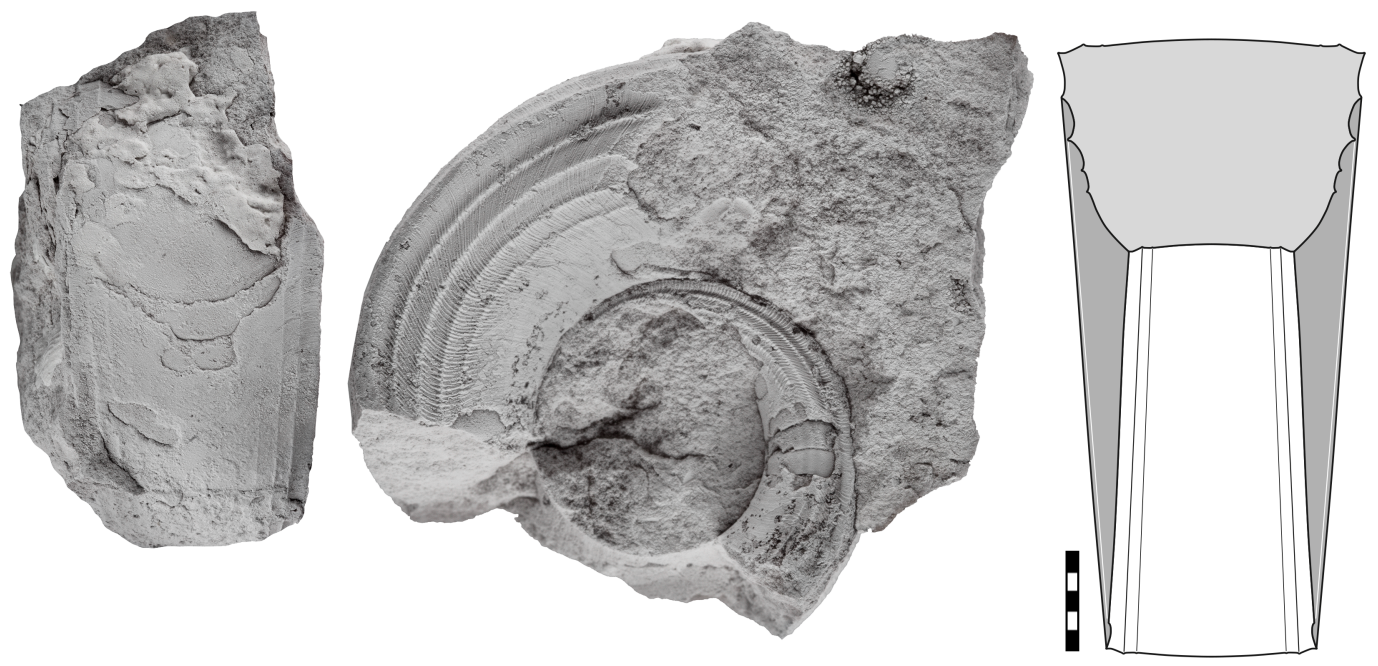

Fig. 11. Vestinautilus concinnus sp. nov., holotype MB.C.30384. Scale bar units $=1 \mathrm{~mm}$.

from most species of the genus including $V$. padus sp. nov. A fairly similar species is only $V$. semiglaber, but this species has seven spiral ridges on the flank ( $V$. concinnus sp. nov. has only four) and a weakly concave venter (convex in V. concinnus sp. nov.) (Foord 1900).

Genus Planetoceras Hyatt, 1893

\section{Type species}

Planetoceras retardatum Hyatt, 1893; original designation.

\section{Diagnosis}

Genus of the family Trigonoceratidae with subevolute conch; whorls slightly impressed; whorl profile rectangular with weakly flattened venter, convex flanks and narrowly rounded umbilical margin. Ornament with fine growth lines, in the preadult stage with fine spiral ridges. Suture line with shallow external and lateral lobes. Siphuncle small with subcentral position (after Kummel 1964; emended).

\section{Included species}

Planetoceras bellilineatum Miller, Dunbar \& Condra, 1933, Kentucky; Planetoceras destrictum sp. nov., Algeria; Nautilus globatus Sowerby, 1824, Ireland; Planetoceras invenustum Shimansky, 1967, South Urals; Planetoceras janischewskyi Shimansky, 1967, South Urals; Planetoceras retardatum Hyatt, 1893, Belgium; Nautilus schartimiensis Janischewsky, 1900, South Urals; Planetoceras tiltoni Miller, Dunbar \& Condra, 1933, Iowa; Planetoceras transforme sp. nov., Algeria. 


\section{Remarks}

Planetoceras was an insufficiently described and delimited genus; the type species $P$. retardatum was described by Hyatt (1893: 421) but not illustrated. Kummel (1964: K426) then published a photographic illustration of the type species. Miller et al. (1933: 138), Shimansky (1967: 130) and Histon (1999: 63) provided a more accurate diagnosis of the genus.

\section{Stratigraphic range}

Late Tournaisian to Bashkirian.

Planetoceras destrictum sp. nov. urn:Isid:zoobank.org:act:42BD8B9E-A638-4C4F-9472-0B0EE6AB489E

Figs 12-13; Table 8

\section{Diagnosis}

Species of Planetoceras with moderately depressed, rounded-pentagonal whorl profile (ww/wh 1.65), venter slightly flattened, ventrolateral shoulder broadly rounded. Umbilical margin subangular to narrowly rounded, umbilical wall steep, flattened. Whorls slightly embracing.

\section{Etymology}

After the Latin 'destrictum', meaning 'sharp' and referring to the angular umbilical margin.

\section{Type material}

\section{Holotype}

ALGERIA • Gourara, Sebkha de Timimoun $14.5 \mathrm{~km}$ west-southwest of Timimoun; "Dalle à Merocanites" (Tournaisian-Viséan boundary interval); illustrated in Fig. 12; MB.C.30385.

\section{Description}

Specimen MB.C.30385 is a fully chambered specimen with a diameter of $67 \mathrm{~mm}$ (Fig. 12). It is a stout, subinvolute conch $(\mathrm{ww} / \mathrm{dm}=0.76 ; \mathrm{uw} / \mathrm{dm}=0.29)$ and has a depressed, subtrapezoidal whorl profile with a broadly rounded venter, a rounded ventrolateral shoulder, weakly flattened, slightly converging flanks,
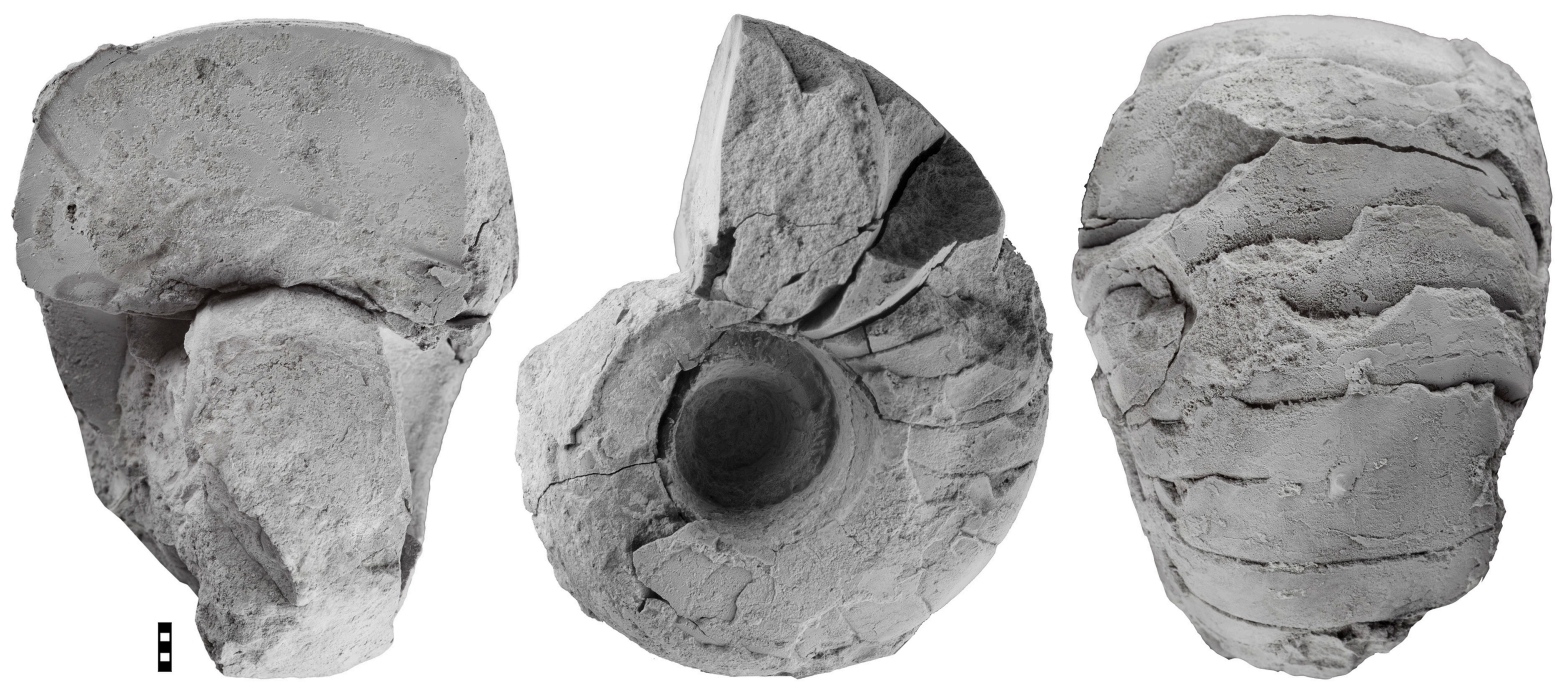

Fig. 12. Planetoceras destrictum sp. nov., holotype MB.C.30385. Scale bar units $=1 \mathrm{~mm}$. 
Table 8. Conch dimensions (in $\mathrm{mm}$ ) and ratios of Planetoceras destrictum sp. nov.

\begin{tabular}{ccccccccccc}
\hline Specimen & dm & ww & wh & uw & ah & ww/dm & ww/wh & uw/dm & WER & IZW \\
\hline MB.C.30385 & 67.1 & 50.8 & 30.8 & 19.5 & 25.4 & 0.76 & 1.65 & 0.29 & 2.59 & 0.18 \\
\hline
\end{tabular}

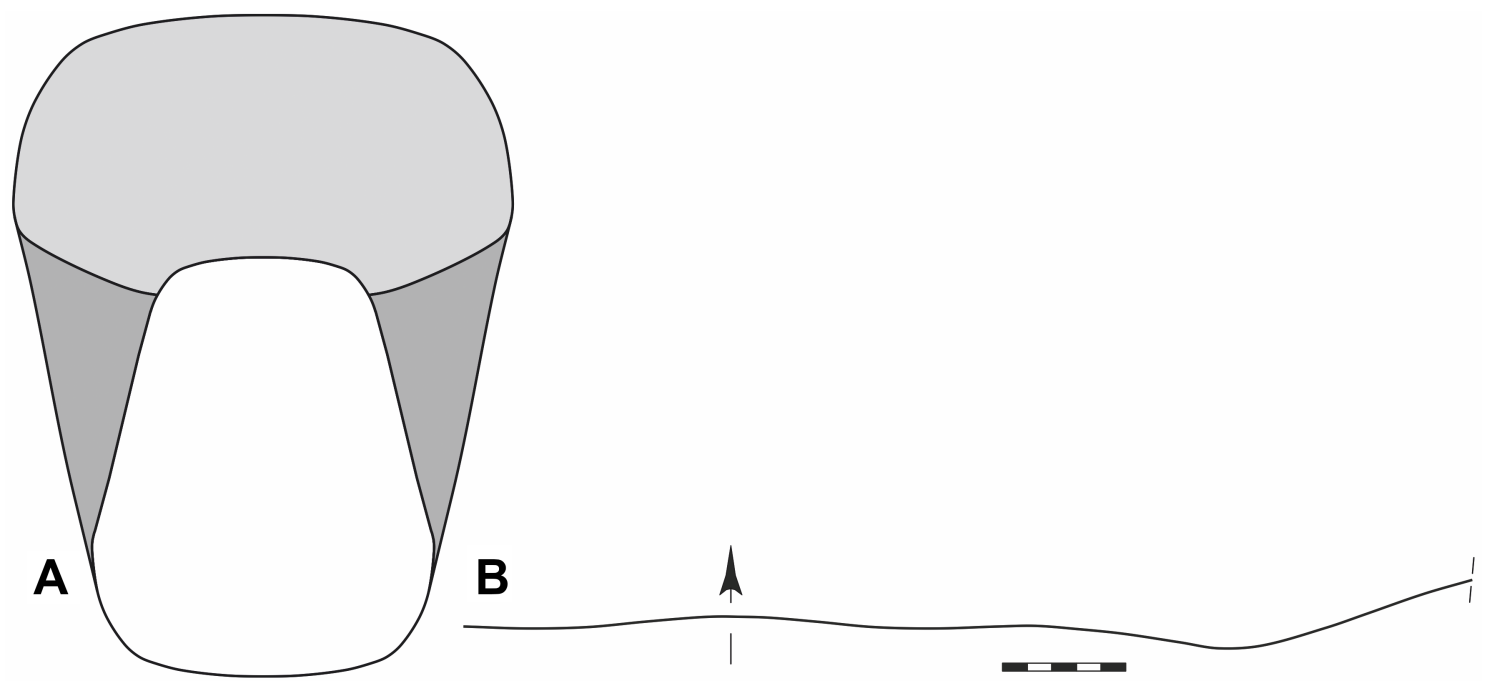

Fig. 13. Planetoceras destrictum sp. nov., holotype MB.C.30385. A. Dorsal view reconstruction. B. Suture line at $52 \mathrm{~mm} \mathrm{dm}, 42 \mathrm{~mm} w w, 22 \mathrm{~mm}$ wh. Scale bar units $=1 \mathrm{~mm}$.

a rounded umbilical margin and a rounded umbilical wall. It has a very high coiling rate (WER $=2.59$ ). The specimen shows a morphological change in the shape of the umbilicus. During the last volution of the phragmocone, the umbilical margin changes from subangular to rounded. At the same time, the umbilical wall changes from flattened to rounded. The suture line extends nearly linearly across the venter and possesses a very shallow lobe on the flank (Fig. 13).

\section{Remarks}

Planetoceras destrictum sp. nov. differs from the species described from Belgium, the South Urals and North America in the flattened venter, which is rounded in those species. More similar is P. globatum (Sowerby, 1824), a species with a very similar whorl profile (Histon 1999) but a more slender conch (ww/dm $\sim 0.55$ at $58 \mathrm{~mm} \mathrm{dm}$ ) than P. destrictum sp. nov. (ww/dm $\sim 0.76$ at $67 \mathrm{~mm} \mathrm{dm}$ ). Planetoceras transforme sp. nov. (described below) has a much stouter conch (ww/dm $\sim 0.85)$.

Planetoceras transforme sp. nov. urn:1sid:zoobank.org:act:CDD3B745-0819-4EA2-8728-D0CAB8CE609B

Fig. 14; Table 9

\section{Diagnosis}

Species of Planetoceras with moderately depressed, rounded-pentagonal whorl profile (ww/wh > 2.00 ), venter slightly flattened, ventrolateral shoulder broadly rounded. Umbilical margin changes 
Table 9. Conch dimensions (in $\mathrm{mm}$ ) and ratios of Planetoceras transforme sp. nov.

\begin{tabular}{ccccccccccc}
\hline Specimen & dm & ww & wh & uw & ah & ww/dm & ww/wh & uw/dm & WER & IZW \\
\hline MB.C.30386 & 43.8 & 37.4 & 18.0 & 11.8 & 16.5 & 0.85 & 2.08 & 0.27 & 2.57 & 0.08 \\
MB.C.30386 & 27.8 & 23.0 & 11.1 & 10.2 & 10.3 & 0.83 & 2.07 & 0.37 & 2.52 & 0.07 \\
\hline
\end{tabular}

from subangular to rounded, umbilical wall steep, changing from flattened to rounded. Whorls slightly embracing.

\section{Etymology}

After the Latin 'transforme', meaning 'changing', because of the rapid early ontogenetic change in morphology.

\section{Type material}

\section{Holotype}

ALGERIA • Gourara, Sebkha de Timimoun $14.5 \mathrm{~km}$ west-southwest of Timimoun; "Dalle à Merocanites" (Tournaisian-Viséan boundary interval); illustrated in Fig. 14; MB.C.30386.

\section{Description}

Holotype MB.C.30386 consists of the first whorl with a diameter of about $28 \mathrm{~mm}$ (Fig. 14A) and a fragment of the second whorl making a total diameter of $44 \mathrm{~mm}$ (Fig. 14B). The conch is stout and has a subtrapezoidal whorl profile at $28 \mathrm{~mm}$ in diameter and an angular umbilical edge raised by a sharp keel. A vertical, flattened umbilical wall extends from here on one side and a converging flank on the other. At a short distance from the umbilical margin there is a pronounced but rounded ventrolateral shoulder. On the broad, slightly flattened venter there is a shallow longitudinal furrow next to the ventrolateral shoulder. Half a whorl before, at about $16 \mathrm{~mm}$ in diameter, the whorl profile is oval and depressed; at this diameter four longitudinal ridges are present. Of these, the innermost one becomes the ridge on the umbilical margin during the next half whorl, and the second one becomes the ridge at the inside of the ventrolateral shoulder. The third and fourth ridges become weaker and disappear on the next half whorl.

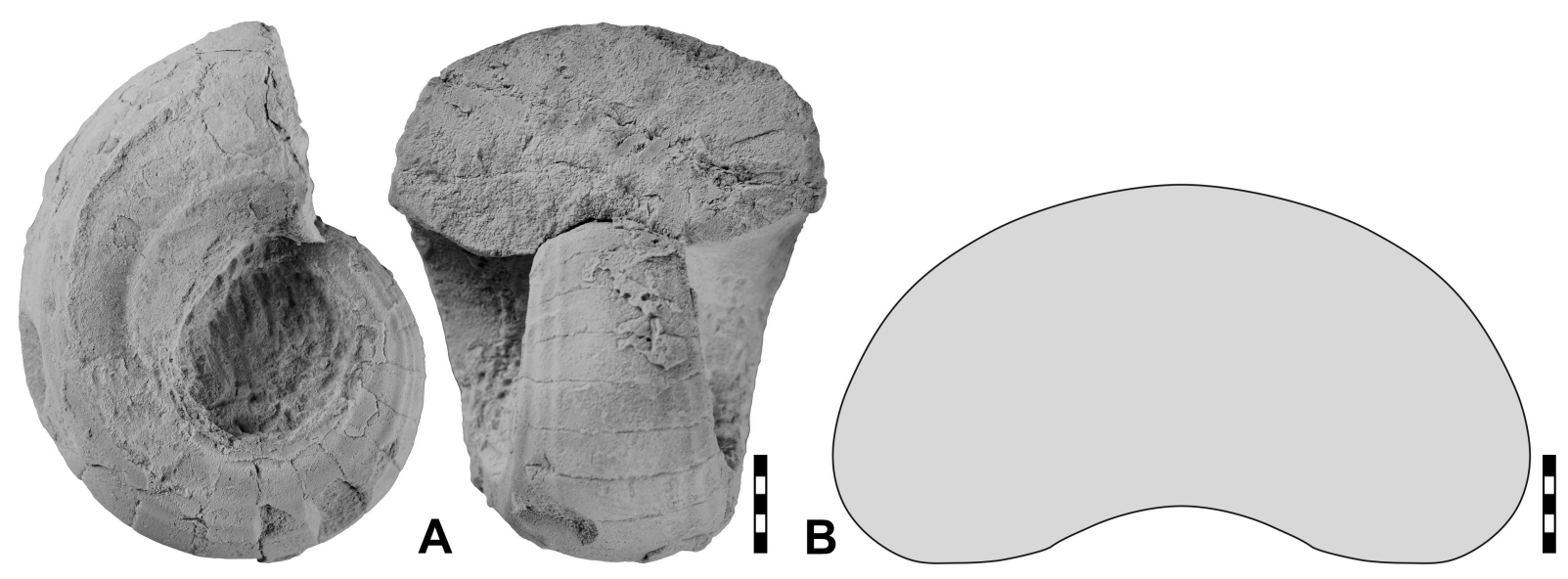

Fig. 14. Planetoceras transforme sp. nov., holotype MB.C.30386. A. Photograph of the inner whorl. B. Whorl profile of a larger phragmocone segment. Scale bar units $=1 \mathrm{~mm}$. 
The suture line extends almost straight across flanks and venter. The fragment of the larger whorl shows that the umbilical margin became rounded at $44 \mathrm{~mm}$ conch diameter (Fig. 14B).

\section{Remarks}

Planetoceras transforme sp. nov. differs from the other species of the genus in the very broad whorl profile (ww/wh > 2.00), which has a value of about 1.60 in other species such as P. destrictum sp. nov. and P. globatum (Histon 1999).

\section{Discussion}

An assemblage of nine species from the Dalle à Merocanites (Tournaisian-Viséan boundary interval) of Timimoun in western Algeria is described. The assemblage consists of the species Maccoyoceras pentagonum sp. nov., Lispoceras orbis sp. nov., Thrincoceras devolvere sp. nov., Rineceras multituberculatum sp. nov., Rineceras rectangulatum sp. nov., Vestinautilus padus sp. nov., Vestinautilus concinnus sp. nov., Planetoceras destrictum sp. nov. and Planetoceras transforme sp. nov.

The frequency distribution of the species within the assemblage is very uneven. While Maccoyoceras pentagonum sp. nov. is represented with 34 specimens and Lispoceras orbis sp. nov. with 15 specimens, the other seven species are present with only one specimen each. It is also significant that all the species discovered belong to a single family, the Trigonoceratidae. This means that the taxonomic diversity is considerably lower than in the time-equivalent assemblages from Belgium (de Koninck 1844, 1878) and Ireland (Foord 1900, 1901; Histon 1999).

A morphometric analysis of the two species represented by several specimens led to the result that the intraspecific variation in these species is within rather narrow limits. Only the coiling rate shows some variation, while the other important conch parameters are rarely variable.

\section{Acknowledgements}

We greatly acknowledge Evelin Stenzel and Markus Brinkmann (Berlin) for the preparation, as well as Jenny Huang (Berlin) for the photography of the specimens. The Deutsche Forschungsgemeinschaft (DFG) provided financial support to DK (project Ko1829/3-1). Luyi Miao thanks the Overseas Research Exchange Program for graduate students of the School of Earth Sciences. We greatly acknowledge the reviews by Martina Aubrechtivá (Prague) and an anonymous reviewer.

\section{References}

Conrad J. 1984. Les séries carbonifères du Sahara central algérien. Stratigraphie, sédimentation, évolution structurale. PhD Thesis, University of Marseille.

de Koninck L.G.D. 1844. Description des animaux fossiles qui se trouvent dans le terrain carbonifère de la Belgique. H. Dessain, Brussels.

de Koninck L.G.D. 1878. Faune du Calcaire Carbonifère de la Belgique. Première partie. Poissons et genre nautile. Annales du Museé royal d'Histoire naturelle de Belgique. Première partie 2: 1-152. https://doi.org/10.5962/bhl.title.149304

de Koninck L.G.D. 1880. Faune du Calcaire Carbonifère de la Belgique, deuxième partie, Genres Gyroceras, Cyrtoceras, Gomphoceras, Orthoceras, Subclymenia et Goniatites. Annales du Museé royal d'Histoire naturelle, Belgique 5: 1-333.

Delépine G. 1939. Nautiloides du Viséen supérieur du Tafilalet(Maroc). Annales de la Société géologique du Nord 64: 63-70. 
Demanet F. 1938. La Faune des Couches de passage du Dinantien au Namurien dans le Synclinorium de Dinant. Mémoires du Museé royal d'Histoire naturelle de Belgique 84: 1-201.

Dzik J. 1984. Phylogeny of the Nautiloidea. Palaeontologia Polonica 45: 1-219.

Dzik J. \& Korn D. 1992. Devonian ancestors of Nautilus. Paläontologische Zeitschrift 66: 81-98. https://doi.org/10.1007/BF02989479

Ebbighausen V., Korn D. \& Bockwinkel J. 2010. The ammonoids from the Dalle à Merocanites of Timimoun (Late Tournaisian-Early Visean; Gourara, Algeria). Fossil Record 13: 153-202.

https://doi.org/10.5194/fr-13-153-2010

Fleming J. 1828. A History of British Animals, Exhibiting the Descriptive Characters and Systematical Arrangement of the Genera and Species of Quadrupeds, Birds, Reptiles, Fishes, Mollusca, and Radiata of the United Kingdom: Including the Indigenous, Extirpated, and Extinct Kinds, Together with Periodical and Occasional Visitants. Bell, Bradfute, Duncan, Edinburgh, London. https://doi.org/10.5962/bhl.title.12859

Foord A.H. 1891. Catalogue of the Fossil Cephalopoda in the British Museum, part II. Containing the Remainder of the Suborder Nautiloidea, Consisting of the Families Lituitidae, Trochoceratidae, and Nautilidae, with a Supplement. Order of the Trustees, London.

Foord A.H. 1900. Monograph on the Carboniferous Cephalopoda of Ireland. Part III. Containing the families Tainoceratidæ, Trigonoceratidæ, Triboloceratidæ, Rineceratidæ, Coloceratidæ, and Solenocheilidæ (in part). Monographs of the Palaeontographical Society 54: 49-126.

https://doi.org/10.1080/02693445.1900.12035492

Foord A.H. 1901. Monograph on the Carboniferous Cephalopoda of Ireland. Part IV. Containing the families Solenocheilidæ (Concluded) and Glyphioceratidæ. Monographs of the Palaeontographical Society 55: 127-146. https://doi.org/10.1080/02693445.1901.12035497

Histon K. 1999. A revision of A.H. Foord's monograph of Irish Carboniferous nautiloid cephalopods (1897-1901). Part 2. Monographs of the Palaeontographical Society 153: 63-129.

Holzapfel E. 1889. Die Cephalopoden-führenden Kalke des unteren Carbon von Erdbach-Breitscheid bei Herborn. Palaeontologische Abhandlungen, Neue Folge 5: 1-74.

Hyatt A. 1883-1884. Genera of fossil cephalopods. Proceedings of the Boston Society of Natural History 22: 253-338.

Hyatt A. 1893. Carboniferous cephalopods. Second paper. Annual Report of the Geological Survey of Texas 4: 377-474.

Klug C., Korn D., Landman N.H., Tanabe K., De Baets K. \& Naglik C. 2015. Describing ammonoid conchs. In: Klug C., Korn D., De Baets K., Kruta I. \& Mapes R.H. (eds) Ammonoid Paleobiology: from Macroevolution to Paleogeography, Topics in Geobiology 44: 3-24. Springer, Dordrecht. https://doi.org/10.1007/978-94-017-9630-9_1

Korn D. 2010. A key for the description of Palaeozoic ammonoids. Fossil Record 13: 5-12. https://doi.org/10.1002/mmng.200900008

Kummel B. 1964. Nautiloidea-Nautilida. In: Moore R.C. (ed.) Treatise on Invertebrate Paleontology: K383-K466. The Geological Society of America and the University of Kansas Press, Lawrence, KS.

M'Coy F. 1844. A Synopsis of the Characters of the Carboniferous Limestone Fossils of Ireland. University Press, Dublin. https://doi.org/10.5962/bhl.title.11559

Martin W. 1793. Figures and Descriptions of Petrifications collected in Derbyshire. Wigan, Lyon. 
Martin W. 1809. Petrificata Derbiensia: or, Figures and Descriptions of Petrifactions Collected in Derbyshire. Vol. 1. Wigan, Lyon. https://doi.org/10.5962/bhl.title.119699

Miller A.K., Dunbar C. \& Condra G.E. 1933. The nautiloid cephalopods of the Pennsylvanian system in the Mid-Continent region. Nebraska Geological Survey Bulletin 9: 1-240.

Miller A.K. \& Garner H. 1953. Lower Mississippian cephalopods of Michigan. Part II. Coiled nautiloids. Museum of Paleontology, University of Michigan.

Niko S. \& Mapes R.H. 2015. Early Carboniferous nautiloids from the Ruddell Shale Member in Arkansas, Midcontinent North America. Paleontological Research 19: 52-60. https://doi.org/10.2517/2014PR029

Niko S. \& Mapes R.H. 2016. Coiled nautiloids from the lower Carboniferous Fayetteville Formation in Arkansas, Midcontinent North America. Paleontological Research 20: 7-17. https://doi.org/10.2517/2015PR017

Schmidt H. 1951. Nautiliden aus deutschem Unterkarbon. Paläontologische Zeitschrift 24: 23-57. https://doi.org/10.1007/BF03044551

Shimansky V.N. 1967. Kamennougol'nye Nautilida. Trudy Paleontologicheskogo Instituta Akademiya Nauk SSSR 115: 1-244.

Sowerby J.D.C. 1825. The Mineral Conchology of Great Britain; or Coloured Figures and Descriptions of those Remains of Testaceous Animals or Shells, which have been Preserved at Various Times and Depths in the Earth: Vol. 5. Richard Taylor, London.

Turner J.S. 1953. The nautiloids named in Martin's "Petrificata Derbiensia, 1809". Annals and Magazine of Natural History 6: 689-692. https://doi.org/10.1080/00222935308654470

Turner J.S. 1954. On the Carboniferous nautiloids: some Middle Viséan species from the Isle of Man. Liverpool and Manchester Geological Journal 1: 298-325.

Winchell A. 1862. Notice of the rocks lying between the Carboniferous limestone of the Lower Peninsula of Michigan and the limestones of the Hamilton group; with descriptions of some cephalopods supposed to be new to science. American Journal of Science and Arts 33: 352-366. https://doi.org/10.2475/ajs.s2-33.99.352

Manuscript received: 28 September 2021

Manuscript accepted: 18 November 2021

Published on: 28 January 2022

Topic editor: Christian de Muizon

Desk editor: Kristiaan Hoedemakers

Printed versions of all papers are also deposited in the libraries of the institutes that are members of the EJT consortium: Muséum national d'histoire naturelle, Paris, France; Meise Botanic Garden, Belgium; Royal Museum for Central Africa, Tervuren, Belgium; Royal Belgian Institute of Natural Sciences, Brussels, Belgium; Natural History Museum of Denmark, Copenhagen, Denmark; Naturalis Biodiversity Center, Leiden, the Netherlands; Museo Nacional de Ciencias Naturales-CSIC, Madrid, Spain; Real Jardín Botánico de Madrid CSIC, Spain; Zoological Research Museum Alexander Koenig, Bonn, Germany; National Museum, Prague, Czech Republic. 